\author{
RESEARCH ARTICLE \\ 10.1029/2018JB016888 \\ Key Points: \\ - The northern Laramide region of \\ southwest Montana preserves an \\ early Laramide exhumation \\ signature starting no later than ca. \\ $80 \mathrm{Ma}$ and as early as ca. $100 \mathrm{Ma}$ \\ - Early Cenozoic cooling and \\ exhumation, and by inference \\ Laramide deformation, is limited in \\ southwest Montana; some cooling \\ post $40 \mathrm{Ma}$ is consistent with core \\ complex and Basin-and-Range \\ tectonics \\ - Flat-slab subduction in the northern \\ Laramide region requires a \\ reevaluation of current models of \\ spatiotemporal trajectory and extent \\ of the Shatsky conjugate plateau
}

Supporting Information:

- Supporting Information S1

- Table S1

- Table S2

- Table S3

- Table S4

- Table S5

Correspondence to:

B. Carrapa,

bcarrapa@email.arizona.edu

Citation:

Carrapa, B., DeCelles, P. G., \& Romero, M. (2019). Early inception of the Laramide orogeny in southwestern Montana and northern Wyoming: Implications for models of flat-slab subduction. Journal of Geophysical Research: Solid Earth, 124, 2102-2123. https://doi.org/10.1029/2018JB016888

Received 16 OCT 2018 Accepted 4 JAN 2019

Accepted article online 9 JAN 2019 Published online 16 FEB 2019

(C)2019. American Geophysical Union. All Rights Reserved.

\section{Early Inception of the Laramide Orogeny in Southwestern Montana and Northern Wyoming: Implications for Models of Flat-Slab Subduction}

\author{
B. Carrapa ${ }^{1}$ (D) P. G. DeCelles ${ }^{1}$ (D), and M. Romero ${ }^{1,2}$ (D) \\ ${ }^{1}$ Department of Geosciences, University of Arizona, Tucson, AZ, USA, ${ }^{2}$ Now at Earth, Atmospheric, and Planetary \\ Sciences Department, Purdue University, West Lafayette, IN, USA
}

\begin{abstract}
Timing and distribution of magmatism, deformation, exhumation, and basin development have been used to reconstruct the history of Laramide flat-slab subduction under North America during Late Cretaceous-early Cenozoic time. Existing geodynamic models, however, ignore a large $\left(\sim 40,000-\mathrm{km}^{2}\right)$ sector of the Laramide foreland in southwestern Montana. The Montana Laramide ranges consist of Archean basement arches (fault-propagation folds) that were elevated by thrust and reverse faults. We present new thermochronological and geochronological data from six Laramide ranges in southwestern Montana (the Beartooth, Gravelly, Ruby and Madison Ranges, and the Tobacco Root and Highland Mountains) that show significant cooling and exhumation during the Early to mid-Cretaceous, much earlier than the record of Laramide exhumation in Wyoming. These data suggest that Laramide-style deformation-driven exhumation slightly predates the eastward sweep of magmatism in western Montana, consistent with geodynamic models involving initial strain propagation into North American cratonic rocks due to stresses associated with a northeastward expanding region of flat-slab subduction. Our results also indicate various degrees of Cenozoic heating and cooling possibly associated with westward rollback of the subducting Farallon slab, followed by Basin-and-Range extension.
\end{abstract}

Plain Language Summary The Laramide region in the western U.S. is characterized by some of the highest topography in North America including the Wind River Range in WY and the Beartooth Range of WY and Montana. These ranges have fed detritus to surrounding basins for millions of years and contributed to modern ecosystems. These high topographic features and basins have significantly impacted paleoenvironmental conditions over geological time. The formation of these high-relief ranges has been linked to deep Earth, geodynamic, processes involving subduction of a flat slab under the North American Plate. Models of flat-slab subduction rely on the timing and pattern of deformation and exhumation of Laramide ranges, which remains poorly understood. Our study provides new data on the timing of deformation and exhumation of Laramide ranges in SW Montana and northern WY capable of testing current models of flat-slab subduction.

\section{Introduction}

The Laramide orogenic event in the western interior U.S. is typified by basement-involved uplifts and intervening basins and inboard migration of igneous activity from the continental margin magmatic arc more than 1,000 km into the western interior U.S. during the Late Cretaceous-early Cenozoic (Behr \& Smith, 2016; Bird, 1998; Brown, 1988; Chapin \& Cather, 1983; Coney \& Reynolds, 1977; DeCelles, 2004; Dickinson \& Snyder, 1978; Erslev, 1993; Henderson et al., 1984; Humphreys, 2009; Humphreys et al., 2015; Jordan, 1981; Jordan \& Allmendinger, 1986; Jones et al., 2011; Liu et al., 2008, 2010; Livaccari et al., 1981; Saleeby, 2003; Snyder et al., 1976; Tarduno et al., 1985). The Laramide event also involved a transition from relatively localized flexural subsidence in front of the Cordilleran thrust belt (Jordan, 1981; Roberts \& Kirschbaum, 1995) to much broader regional subsidence (Bird, 1984; Cross \& Pilger, 1978; Liu \& Nummedal, 2004; Mitrovica et al., 1989; Painter \& Carrapa, 2013), followed by locally compartmentalized subsidence associated with individual Laramide uplifts and basins (Dickinson et al., 1988; Lawton, 1983, 2008). The structural style and peculiar magmatic history of the Laramide region (Figure 1) distinguish it from the remainder of the Cordilleran orogenic belt. Since the 1970s, the Laramide event has been interpreted to be the result of upper plate deformation in response to low-angle or flat-slab subduction, but the causes of flat-slab subduction are still debated (e.g., Bird, 1984, 1998; Coney \& Reynolds, 1977; Dickinson \& Snyder, 


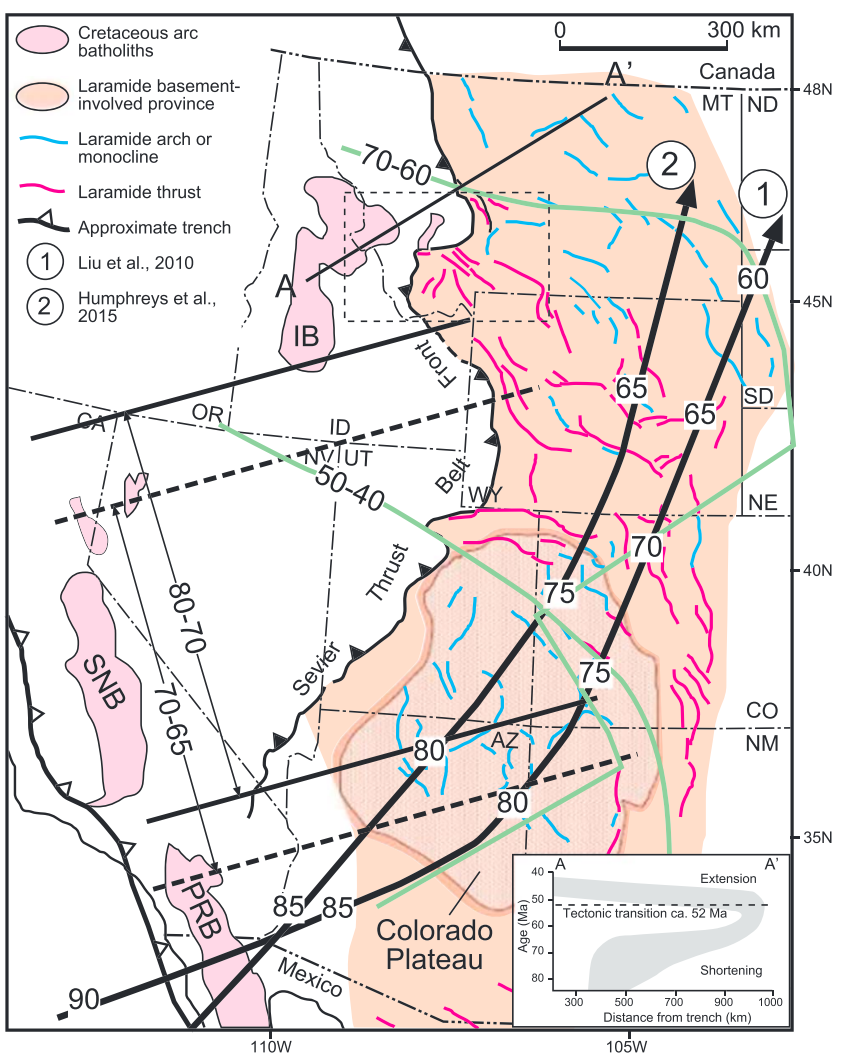

Figure 1. Map of western U.S., showing distribution of major Cretaceous arc batholiths (Idaho (IB), Sierra Nevada (SNB), and Peninsular Range (PRB) batholiths), the front of the Sevier fold-thrust belt, Colorado Plateau, and the area in which Laramide basement-involved structures are present, incorporating elements of Dickinson et al. (1988), DeCelles (2004), Saleeby (2003), Lawton (2008), Liu et al. (2010), Yonkee and Weil (2015), and Axen et al. (2018). Two proposed Shatsky conjugate plateau trajectories are shown with bold lines labeled 1 and 2, annotated with times (in Ma) at which the plateau arrived at given locations. Straight black solid and dashed lines trending east-northeast delineate regions of flat slab proposed at labeled times by Cross (2009). Green lines indicate locations of flat slab hinge line at labeled times according to Bird (1998). Inset (lower right) shows history of the magmatic sweep across section line A-A'. Distance from trench refers to palinspastic distance east of the inferred location of the trench at $20 \mathrm{Ma}$; modified after Constenius et al. (2003). Dashed rectangle in southwestern Montana shows area of Figure 2.
1978; Henderson et al., 1984; Jones et al., 2011; Jordan \& Allmendinger, 1986; Lipman et al., 1971; Liu et al., 2010).

Explanations of Laramide flat-slab subduction can be categorized as (1) those that attribute slab flattening to features of the subducting plate (e.g., Henderson et al., 1984; Liu et al., 2010; Livaccari et al., 1981; Saleeby, 2003) and (2) those that see the flat slab as a result of interactions between both upper and lower plates in the context of global plate kinematics and local geometry of the North American craton (e.g., Bird, 1998; Engebretson et al., 1985; Jones et al., 2011). Among the first class of models are those that attribute flattening of the slab to subduction of buoyant oceanic plateaux or aseismic ridges (e.g., Henderson et al., 1984; Liu et al., 2010; Saleeby, 2003). This view finds support from modern examples of flat-slab subduction beneath western South America that are associated with oceanic aseismic ridges (e.g., Gutscher, 2000). Recent numerical models (Axen et al., 2018; Liu et al., 2008, 2010) posit that an oceanic plateau on the Farallon plate-referred to as the Shatsky conjugate plateau after its modern counterpart in the northwest Pacific basin - collided with the coastline of southwestern North America and subsequently was subducted at low angle along an approximately northeastward trajectory beneath the Laramide region of Arizona, New Mexico, Utah, Wyoming, and Colorado. Although the northeastward trajectory of the hypothetical Shatsky conjugate is consistent with some kinematic indicators from Laramide uplifts (Erslev, 1993, 2005; Bird, 1998), Bird (1998) noted that plateau subduction alone cannot explain the greater than 35-Myr duration of the Laramide event, given the rapid rate of plate convergence during this time interval. Moreover, many of these models invoke a relatively narrow flat-slab corridor trending approximately $\mathrm{N} 15^{\circ} \mathrm{E}$ (Axen et al., 2018; Saleeby, 2003), which fails to explain the broad extent of Laramide basement block uplifts from the Mexican border to north central Montana. In constrast, Dickinson and Snyder (1978) and Bird (1984, 1998) argued that basal traction on the North American plate by east-northeastward and horizontally subducting Farallon lithosphere transmitted shear stress into the crust, which deformed along preexisting heterogeneities. These and other early models for the Laramide (e.g., Cross, 2009; Cross \& Pilger, 1978) depicted a much broader and temporally variable extent of flat-slab subduction, directed along an azimuth of approximately $\mathrm{N} 65^{\circ} \mathrm{E}$, which is consistent with regional shortening directions in the Laramide uplifts (Erslev \& Koenig, 2009; Hamilton, 1988). Models in the second class attribute initial low-angle subduction to increased rate and orthogonality of convergence (Engebretson et al., 1985); slab flattening is subsequently enhanced by differential pressure in the mantle associated with constricted asthenospheric return flow in the vicinity of the deep keel of the Wyoming craton (Jones et al., 2011).

Assessment of these and other models for the Laramide event hinges on the availability of accurate estimates for the timing of the Laramide uplifts. Unfortunately, the timing of Laramide structural events has been difficult to date directly because the rocks involved in the uplifts have not been metamorphosed since the Precambrian, the kinematic events involved in the Laramide were largely amagmatic, and few studies have been able to assess the low-temperature thermochronological ages of Laramide block exhumation (e.g., Copeland et al., 2017; Fan \& Carrapa, 2014; Kelley, 2005; Omar et al., 1994; Peyton et al., 2012; Peyton \& Carrapa, 2013). Thus, the timing of Laramide flat-slab subduction has been inferred from the timing and spatial distribution of regionally inboard migrating magmatism (e.g., Coney \& Reynolds, 1977; Constenius et al., 2003) and the timing of Laramide synorogenic sedimentation and basin development (e.g., Amato et al., 2017; Crews \& Ethridge, 1993; Dickinson et al., 1988; DeCelles et al., 1987, 1991; Graham et al., 1986; Hoy \& Ridgway, 1997; Ingersoll et al., 1987; Keefer, 1970; Lawton, 1983, 2008; Nichols et al., 1985; Ryder \& 


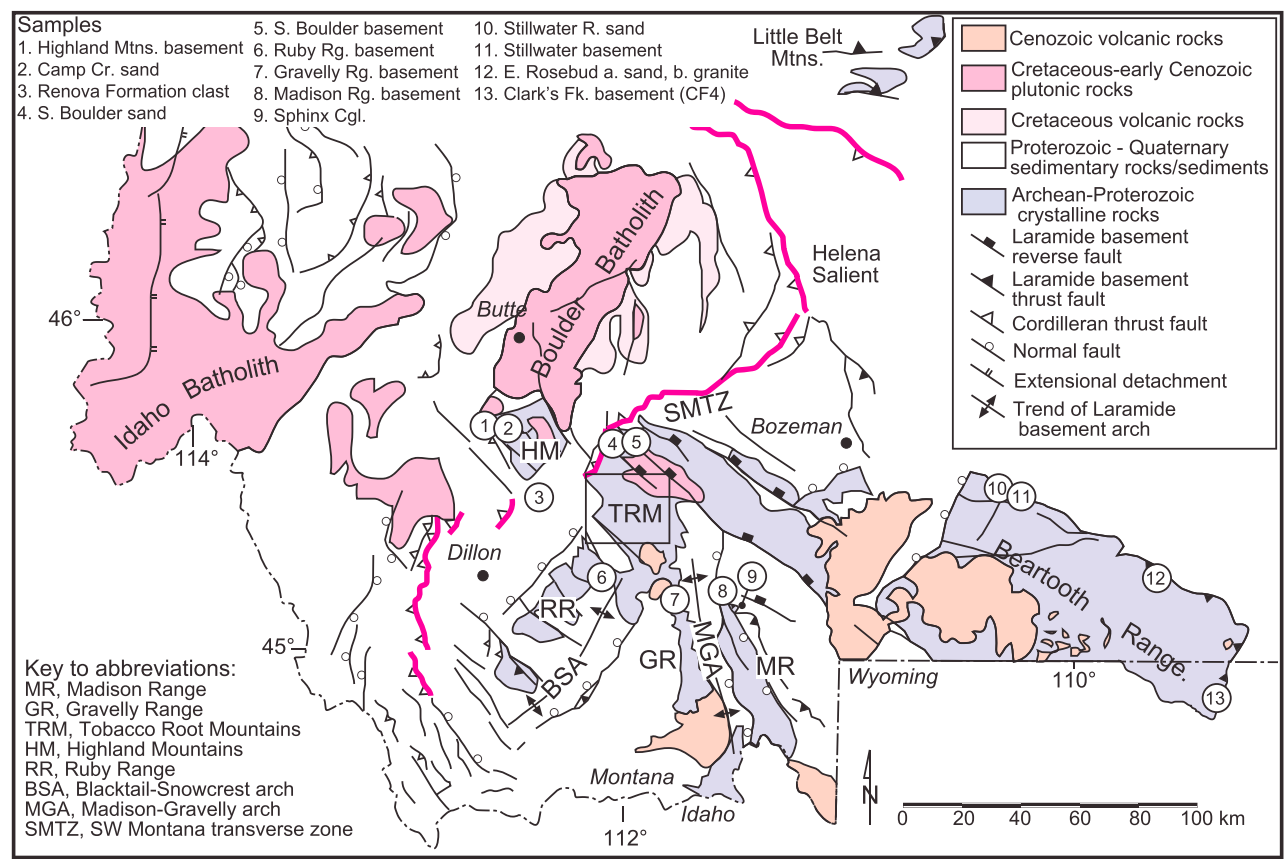

Figure 2. Simplified geologic map of southwestern Montana highlighting Laramide basement uplifts, Cordilleran thinskinned thrust faults, and Late Cretaceous-mid Cenozoic igneous rocks, modified after Schmidt and Garihan (1983) and Vuke et al. (2007). Frontal Cordilleran thin-skinned thrust is shown as red barbed line west of Dillon, along the SMTZ, and along the eastern margin of the Helena salient. Note that thin-skinned Cordilleran thrust faults impinge on Laramide basement structures in the Highland and Tobacco Root Mountains. Box in Tobacco Root Mountains (TRM) indicates area of the Brady et al. (2004) study referred to in text.

Scholten, 1973; Suttner et al., 1981). This approach cannot be used for most of the Colorado Plateau Laramide uplifts, which lack syntectonic basin counterparts (for a possible exception, see Tindall et al., 2010); in any case many of the synorogenic deposits do not capture the timing of initial Laramide unroofing (e.g., Crews \& Ethridge, 1993; DeCelles et al., 1991; Hoy \& Ridgway, 1997) and the deposits are difficult to precisely date.

A second important issue with recently published models for the Laramide orogenic event (Axen et al., 2018; Jones et al., 2011; Liu et al., 2010; Saleeby, 2003) is that they do not accommodate southwestern Montana (Figures 1 and 2), a region encompassing some $40,000 \mathrm{~km}^{2}$ of the Laramide foreland with at least eight major, basement-involved uplifts (Kulik \& Schmidt, 1988). Like the classic Laramide uplifts of Wyoming and the Colorado Plateau, the Montana Laramide structures are asymmetric, thrust- and reverse-faultbounded, Archean basement arches that can be modeled as large fault-propagation folds (Blackstone, 1986; Brown, 1988; DeCelles et al., 1991; Erslev, 1991; Gries, 1983; Hoy \& Ridgway, 1997; Schmidt \& Garihan, 1983; Stone, 1985); they are clearly separate from the Cordilleran fold-thrust belt, which in its thin-skinned frontal part locally impinges upon the Laramide structures (Kulik \& Schmidt, 1988; Perry et al., 1988; Schmidt et al., 1988; Schmidt \& Garihan, 1983). The Montana Laramide uplifts are 300$500 \mathrm{~km}$ west of recently proposed trajectories of the Shatsky conjugate plateau (e.g., Liu et al., 2010; Axen et al., 2018; Figure 1).

In order to provide new information to help constrain geodynamic models for the Laramide event, we present low-temperature thermochronological data from six Laramide uplifts in southwestern Montana. Our results provide data critical for developing a more complete picture of Laramide kinematic history and for testing and refining geodynamic models for the Laramide event.

\section{Geologic Setting of Southwest Montana Laramide Uplifts}

From Late Jurassic through Paleocene time, eastward subduction of the Farallon oceanic plate beneath the North American plate produced the Cordilleran orogenic belt, which extends from central Mexico to the 
Alaskan and Canadian Arctic (Colpron et al., 2007; DeCelles, 2004; Dickinson, 2004; Yonkee \& Weil, 2015). Flanking the orogenic belt on the east was a continental-scale retroarc foreland basin (DeCelles, 2004; Miall et al., 2008; Plint et al., 2012). At the latitude of southwestern Montana during the Late Cretaceous, the orogen consisted of an outboard accretionary belt, a continental-margin magmatic arc, and an eastward verging retroarc fold-thrust belt (e.g., Dickinson, 2004; Gaschnig et al., 2010; Goldstrand, 1994; Lund \& Snee, 1988; Perry et al., 1988; Schmidt et al., 2016). Deformation in the fold-thrust belt overlapped temporally with Laramide thick-skinned deformation to the east between ca. 85 and 40 Ma (e.g., DeCelles, 2004; Yonkee $\&$ Weil, 2015). In southwestern Montana, the front of the fold-thrust belt forms an arcuate, eastward concave reentrant west of Dillon that is connected via the Southwest Montana Transverse zone (SMTZ; Schmidt \& O'Neill, 1982) to the eastward convex Helena salient (Figure 2). The SMTZ is a system of oblique thrusts and strike-slip faults that reactivated the southern margin of an east trending Proterozoic rift (McMannis, 1963; Schmidt \& O'Neill, 1982; Schmidt \& Garihan, 1983). Archean crust was offset downward to the north across this boundary during Proterozoic time (McMannis, 1963), thus helping to explain the abrupt northward termination of local Laramide structures.

The Laramide foreland of southwestern Montana contains at least eight, major basement uplifts that, together, form the northwestern corner of the Laramide structural province, bounded on the north by the SMTZ and on the west by the frontal part of the fold-thrust belt (Figure 2). Thin-skinned thrust faults in the frontal fold-thrust belt locally modified the edges of preexisting foreland basement uplifts (Schmidt \& Garihan, 1983; Schmidt et al., 1988; Ruppel \& Lopez, 1984). The basement rocks that form the Laramide uplifts were structurally elevated along roughly north trending foreland arches in the hanging walls of west and southwest dipping thrust faults and in the hanging walls of northwest striking, northeast dipping, highangle reverse faults of Precambrian ancestry (Figure 2; DeCelles et al., 1987; Garihan et al., 1983; Schmidt \& Hendrix, 1981; Schmidt \& O'Neill, 1982; Schmidt \& Garihan, 1983; Schmidt et al., 1988, 1993). Some of these uplifts have been strongly modified by Miocene Basin-and-Range normal faults. Unlike the Laramide foreland of Wyoming and Utah, the Montana foreland contains a number of granitoid plutons, related volcanic deposits, and hydrothermal mineralization of Late Cretaceous to early Cenozoic ages (ca. 80-64 Ma; Figure 2 ; e.g., du Bray \& Harlan, 1998; Lund et al., 2002; Foster et al., 2002, 2012); magmatism continued to the east until ca. $55 \mathrm{Ma}$ (Constenius et al., 2003, and references therein). In some cases (e.g., the Tobacco Root batholith) plutons intruded the cores of Laramide uplifts (Sarkar et al., 2009; Schmidt \& Garihan, 1983; Schmidt et al., 1990; Tysdal et al., 1986). To the west, the Idaho batholith represents the Cordilleran magmatic arc at the latitude of western Montana; unlike the magmatic arc in California and adjacent Nevada, the Idaho batholith and its satellite plutons were active more or less continuously through Late Cretaceous and early Cenozoic time (du Bray et al., 2012; Gaschnig et al., 2017; Lund et al., 2002).

\section{Timing of Laramide Uplifts: Previous Work}

Various proxies have been used to date the Laramide event, including the ages of coarse-grained synorogenic sedimentary rocks associated with Laramide structures, subsidence histories of Laramide basins, and sedimentary provenance data that record the times of source-rock exposure in Laramide ranges. All of these proxies, however, have inherently large temporal uncertainties. For example, the ages of Laramide synorogenic deposits are commonly poorly constrained because of their coarse grain size and lack of high-resolution biostratigraphic age indicators (e.g., Crews \& Ethridge, 1993; DeCelles et al., 1987, 1991; Fan et al., 2011; Haley, 1986; Haley \& Perry, 1991; Hoy \& Ridgway, 1997). Moreover, synorogenic conglomerates in the Laramide region commonly rest in angular unconformity on upturned preorogenic rocks and therefore postdate initial structural growth and source-terrane erosion (e.g., Crews \& Ethridge, 1993; DeCelles et al., 1991; Hoy \& Ridgway, 1997). Subsidence histories in Laramide basins, which generally lack datable volcanogenic materials, are subject to chronostratigraphic uncertainties. Thermochronological studies also have limitations because the recorded timing of exhumation may long predate and/or initial deformation, such as in the Wind River Range in Wyoming (Fan et al., 2011; Fan \& Carrapa, 2014; Orme et al., 2016; Stevens et al., 2016).

Based on the record of sedimentation in Laramide basins, Dickinson et al. (1988) suggested synchronous initiation of the Laramide uplifts during the Maastrichtian, followed by diachronous termination from north to south between early and late Eocene. Copeland et al. (2017) extended the duration of Laramide activity into the Oligocene. In Utah stratigraphic thinning above the San Rafael Swell suggests Laramide 
structural growth during Campanian time (Guiseppe \& Heller, 1998; Lawton, 1983). Recent work in Utah (Lopez \& Steel, 2015) indicates that Laramide ranges were rising and affecting basin subsidence by ca. $72 \mathrm{Ma}$, and a clear dynamic control (which cannot be explained by flexure) on regional subsidence (considered to be related to flat-slab subduction) is evident since ca. 81 Ma (Cross, 2009; Liu \& Nummedal, 2004; Painter \& Carrapa, 2013). Angular unconformities and stratal thinning patterns indicate that uplift of the Laramide Moxa and Rock Springs arches predated late Campanian time in southwestern Wyoming (Devlin et al., 1993; Leary et al., 2014; Mederos et al., 2005). Tindall et al. (2010) argued that the East Kaibab monocline in southern Utah was active between ca. 76 and 80 Ma. Initiation of the Laramide in New Mexico has been dated to ca. 75-70 Ma, and coeval magmatism suggests that the slab was steep enough to enable melting (Amato et al., 2017). A similar time of Laramide initiation has been shown for Sonora and southeastern Arizona (Clinkscales \& Lawton, 2015). In southwestern Montana, the Maastrichtian Sphinx Conglomerate signals activity on the Scarface thrust, which bounds the eastern flank of the Laramide Madison-Gravelly arch (Figure 2; DeCelles et al., 1987). The Paleocene Beartooth Conglomerate contains growth structures attributable to development of the eastern boundary thrust of the Laramide Beartooth Range (Figure 2; Flueckinger, 1970; DeCelles et al., 1991). These latter two examples, however, provide only minimum ages for the onset of deformation because both synorogenic conglomerates rest in angular unconformity upon preorogenic strata.

The record of basin subsidence in the western U.S. indicates that the transition from classic foreland basin subsidence to longer-wavelength subsidence commenced at 85 Ma (DeCelles, 2004; Gries, 1983; Jordan, 1981). Onset of a regional, dynamic component of subsidence at ca. $81 \mathrm{Ma}$ (Painter \& Carrapa, 2013) is consistent with mantle convection above a shallowly subducting Farallon plate (Gurnis, 1993, Liu \& Nummedal, 2004; Liu et al., 2010; Mitrovica et al., 1989; Pang \& Nummedal, 1995; Spasojevic et al., 2009). Numerical models show that the northeastward progression of a flat slab can fit with the eastward shift of the foreland depocenter (Liu et al., 2008, 2010; Heller \& Liu, 2016). Although this large-scale episode has been dynamically related to flat- or shallow-slab subduction (Gurnis, 1992; Heller \& Liu, 2016; Liu et al., 2008, Mitrovica et al., 1989; Pang \& Nummedal, 1995; Painter \& Carrapa, 2013), identifying a real dynamic subsidence component is challenging as it can be related to different processes. For example, regional dynamic subsidence can be caused by penetration of the subducting slab into the lower mantle (Faccenna et al., 2017; Yang et al., 2016). In any case, the structural partitioning of the Laramide foreland must largely postdate regional dynamic subsidence because Laramide basins disrupted the long-wavelength subsidence pattern.

Low-temperature thermochronological data that document the timing of cooling and erosion associated with deformation of Laramide structures are available for several Laramide ranges in Wyoming (for a review see Peyton \& Carrapa, 2013). Most of the Wyoming ranges that have been studied record Cenozoic cooling (Peyton et al., 2012). Exhumation of the Wind River Range occurred between ca. 60 and 50 Ma (Fan \& Carrapa, 2014; Stevens et al., 2016). Apatite fission track (AFT) and (U-Th[-Sm])/He thermochronology have been applied to Precambrian basement samples of the Beartooth Range (Cerveny \& Steidtmann, 1993; Omar et al., 1994; Peyton et al., 2012; this study) and the Bighorn Range (Crowley et al., 2002; Peyton et al., 2012), revealing a complex Cretaceous to early Cenozoic cooling history. Although cooling in the Beartooth Range initiated earlier than ca. $58 \mathrm{Ma}$, the timing of initiation of exhumation remains largely unconstrained (Peyton et al., 2012). Combined thermochronological, sedimentary provenance, paleoaltimetry, and stratigraphic data indicate two pulses of Laramide uplift, erosion, and basin subsidence in Wyoming: one at ca. $\sim 71 \mathrm{Ma}$ and a second during the Paleocene; the latter was attributed to slab rollback (Fan \& Carrapa, 2014). However, the paucity of data from the northern Laramide region of Montana prevents an assessment of the true spatial pattern of Laramide exhumation. The goal of this study is to determine the tectonothermal history of Laramide ranges in southwestern Montana and adjacent northern Wyoming through the application of zircon $\mathrm{U}-\mathrm{Pb}$ geochronology, AFT, zircon $(\mathrm{U}-\mathrm{Th}[-\mathrm{Sm}]) / \mathrm{He}(\mathrm{ZHe})$, and apatite $(\mathrm{U}-\mathrm{Th}[-\mathrm{Sm}]) / \mathrm{He}(\mathrm{AHe})$ thermochronology of basement rocks and modern river sand samples, and thermal modeling.

\section{Materials and Methods}

\subsection{Zircon U-Pb Geochronology}

Before thermochronological data can be interpreted in terms of exhumation-related cooling, the possibility of magmatic cooling must be ruled out. This issue is acute in southwestern Montana, where Laramide 
structures may have been thermally affected by Late Cretaceous plutonism (e.g., du Bray et al., 2012; Gaschnig et al., 2010, 2017; Lund et al., 2002; Sarkar et al., 2009; Schmidt et al., 1990). In order to constrain the age of crystallization and the timing of magmatic-related processes, zircon $\mathrm{U}-\mathrm{Pb}$ geochronology was applied to four selected basement samples. Analyses were conducted on both rims and cores ( $\mathrm{R}$ and $\mathrm{C}$ in Table S1 and Figure S1 in the supporting information) to evaluate for possible magmatic overgrowths during Cretaceous-Cenozoic magmatism (e.g., Fornash et al., 2013). An average of 20 grains was analyzed for each basement sample; U-Pb results are presented in Figure S1. Analyses were conducted at the University of Arizona LaserChron Center using the Nu multicollector ICPMS. Analytical details are available in the supporting information; more information on zircon U-Pb geochronology and data analyses are available in Stacey and Kramers (1975), Gehrels et al. (2008), and Ludwig (2008).

\subsection{Low-Temperature Thermochronology}

AFT, ZHe, and AHe thermochronology methods were applied to 10 basement samples from the Ruby, Gravelly, Beartooth, and Madison Ranges, and the Highland and Tobacco Root Mountains, along with two conglomerate clasts from the Renova Formation (mid-Eocene-early Miocene; Schwartz \& Schwartz, 2013) and Sphinx Conglomerate (DeCelles et al., 1987; Table 1 and Figure 2). The combination of AFT, $\mathrm{ZHe}$, and $\mathrm{AHe}$ thermochronology provides information on the timing of cooling through the ca. $250{ }^{\circ} \mathrm{C}-40{ }^{\circ} \mathrm{C}$ temperature window (Farley, 2002; Gleadow, Duddy, Green, \& Hegarty, 1986; House et al., 2000; Reiners, 2005; Figures 2 and 3). Detrital AFT was applied to three modern river sand samples derived from the Tobacco Root Mountains and Beartooth Range to constrain the regional cooling signature of these ranges (Figures 2 and 4). For AHe analyses, apatite grains were selected on the basis of clarity, lack of visible inclusions, and half-widths greater than $60 \mu \mathrm{m}$ (Farley et al. 1996). For AFT analysis, apatite grains were separated, mounted, and etched in 5.5-M nitric acid for $20 \mathrm{~s}$ at $21{ }^{\circ} \mathrm{C}$ according to the protocols of Donelick et al. (2005). After irradiation, the mica prints were etched at $21{ }^{\circ} \mathrm{C}$ in $40 \% \mathrm{Hf}$ for 45 min following Donelick et al. (2005) and analyses were conducted at the University of Arizona Fission Track Laboratory. Fission track ages were calculated using the external detector method (Hurford \& Green, 1983). Irradiation was performed at the Oregon State University reactor. AHe and ZHe analyses were performed at the University of Arizona (U-Th[-Sm])/He Laboratory following the methods described in Reiners et al. (2004). An average of five single grains per samples were targeted for (U-Th[-Sm])/He analyses (Tables S2 and S3). More information on U-Th[-Sm])/He analyses can be found in Reiners and Nicolescu (2006).

HeFTy modeling software (Ketcham, 2005; Ketcham et al., 2007) is used to create inverse thermal models of low-temperature thermochronological data. The diameters of fission track etch pits $\left(D_{\text {par }}\right)$ were measured for each AFT-modeled sample in order to determine annealing kinetics (Donelick, 1993); confined lengths were measured when present.

Basement samples with at least 50 measureable confined track lengths are from the Beartooth Range, Ruby Range, Tobacco Root Mountains, and Highland Mountains. Four to six $D_{\text {par }}$ measurements were recorded for each counted grain and for grains with measured confined track lengths in order to account for chemical composition (Donelick, 1993).

Confined track length distributions provide information on the thermal history of a sample (Gleadow, Duddy, Green, \& Lovering, 1986). The temperature window in which tracks anneal in apatite is between $\sim 120{ }^{\circ} \mathrm{C}$ and $\sim 60{ }^{\circ} \mathrm{C}$ and is referred to as the Partial Annealing Zone (PAZ); the time spent within the PAZ governs the annealing process and the confined track lengths (Gleadow, Duddy, Green, \& Lovering, 1986). Inverse thermal modeling using HeFTy (Ketcham, 2005) together with independent geological information allows for the evaluation of the best thermal history for each analyzed sample. A set of likely time temperature histories was generated by inverse modeling for each basement sample based on available AFT ages, confined track lengths, and $D_{\text {par }}$ data; AFT, ZHe, and AHe ages were modeled independently (Figure 5 and Tables 1 and 2).

For AHe data we use the RDAAM calibration model (Flowers et al., 2009), and for ZHe data we used the Guenthner et al. (2013) model combined with the stopping distance calculations from Ketcham et al. (2011). Additional details on model parameters can be found in Table 2. These models exploit the role of radiation damage in apatite and zircons to reconstruct the thermal histories of the sample. Age-eU 


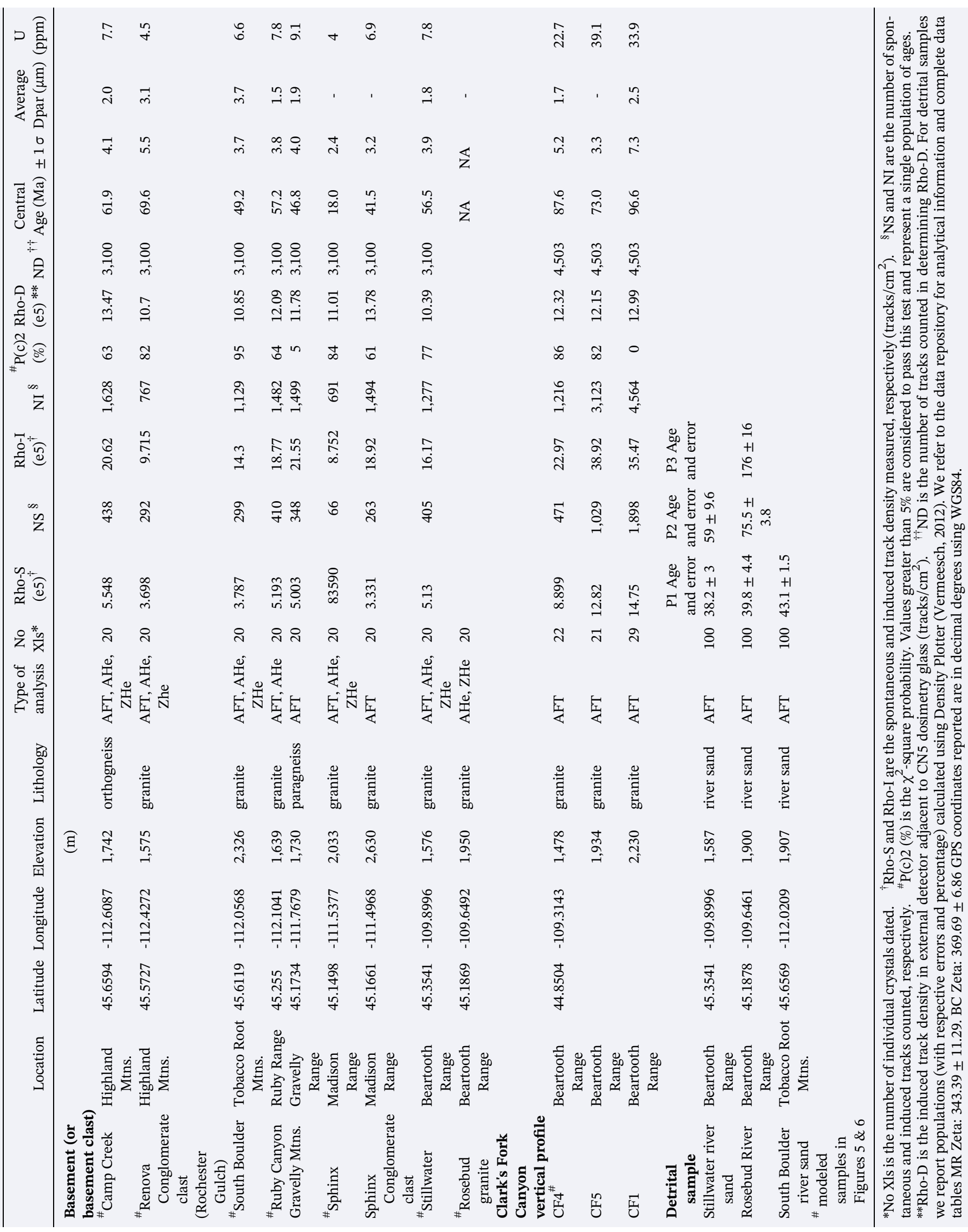




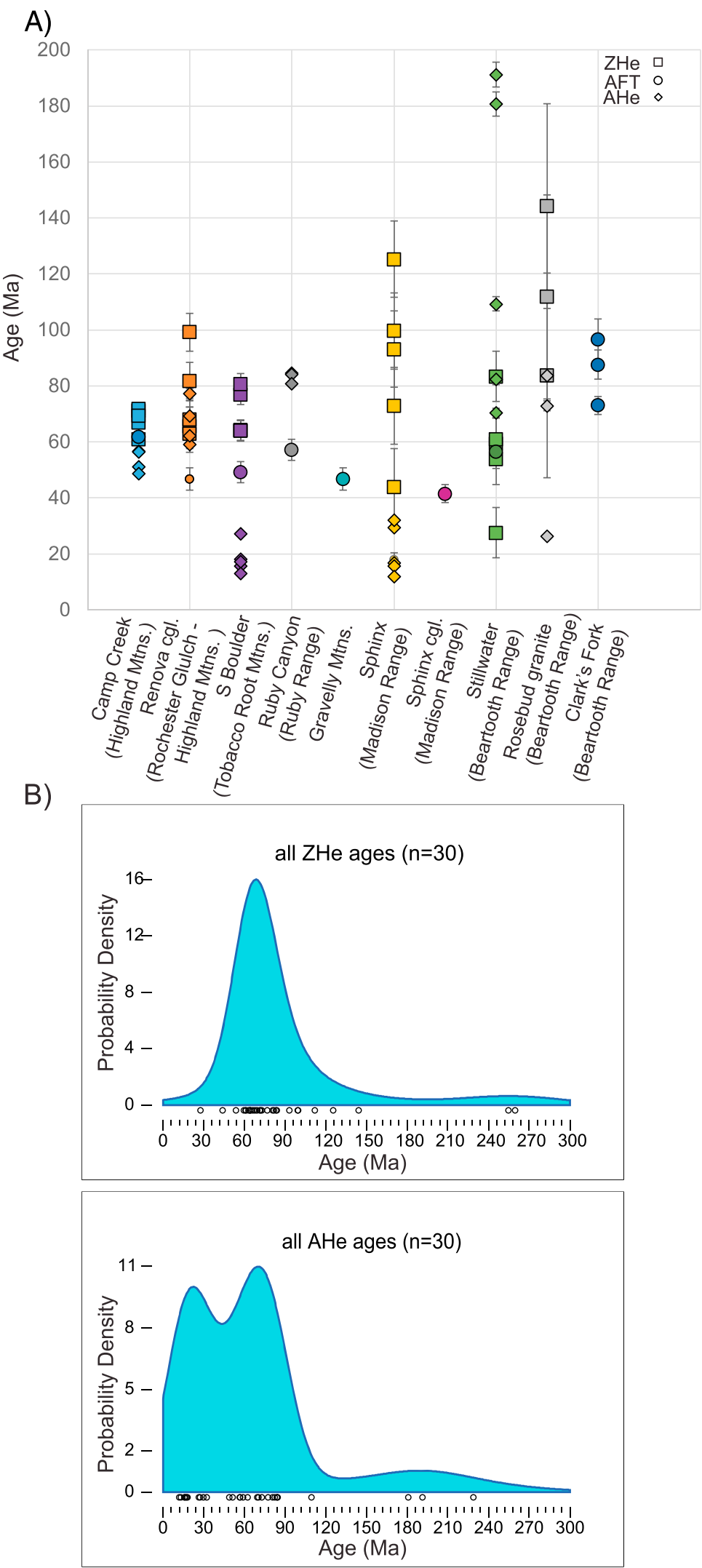

Figure 3. (a) All thermochronological ages from this study (Tables 1, S2, and S3); (b) density kernel function of ZHe and AHe ages from all samples; calculated using Density Plotter (Vermeesch, 2012). 

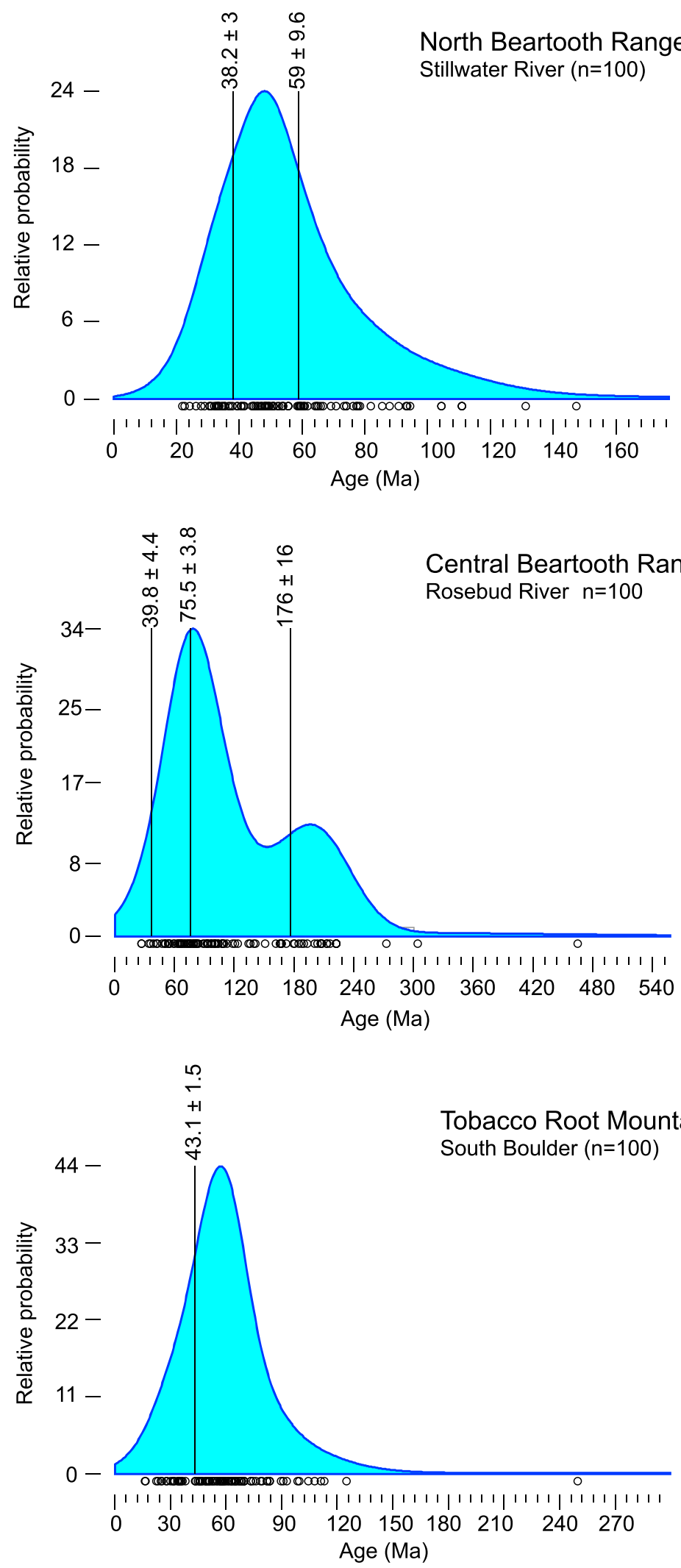

Figure 4. Density kernel functions of detrital AFT ages from modern river sand samples from the Beartooth Range and Tobacco Root Mountains; refer to Figure 2 for sample locations. Open circles on age axis indicate individual ages. Vertical lines and ages represent populations calculated in automated mode using Density Plotter (Vermeesch, 2012). The program was run in automated mode to produce the minimum number of populations (indicated in the figure). 

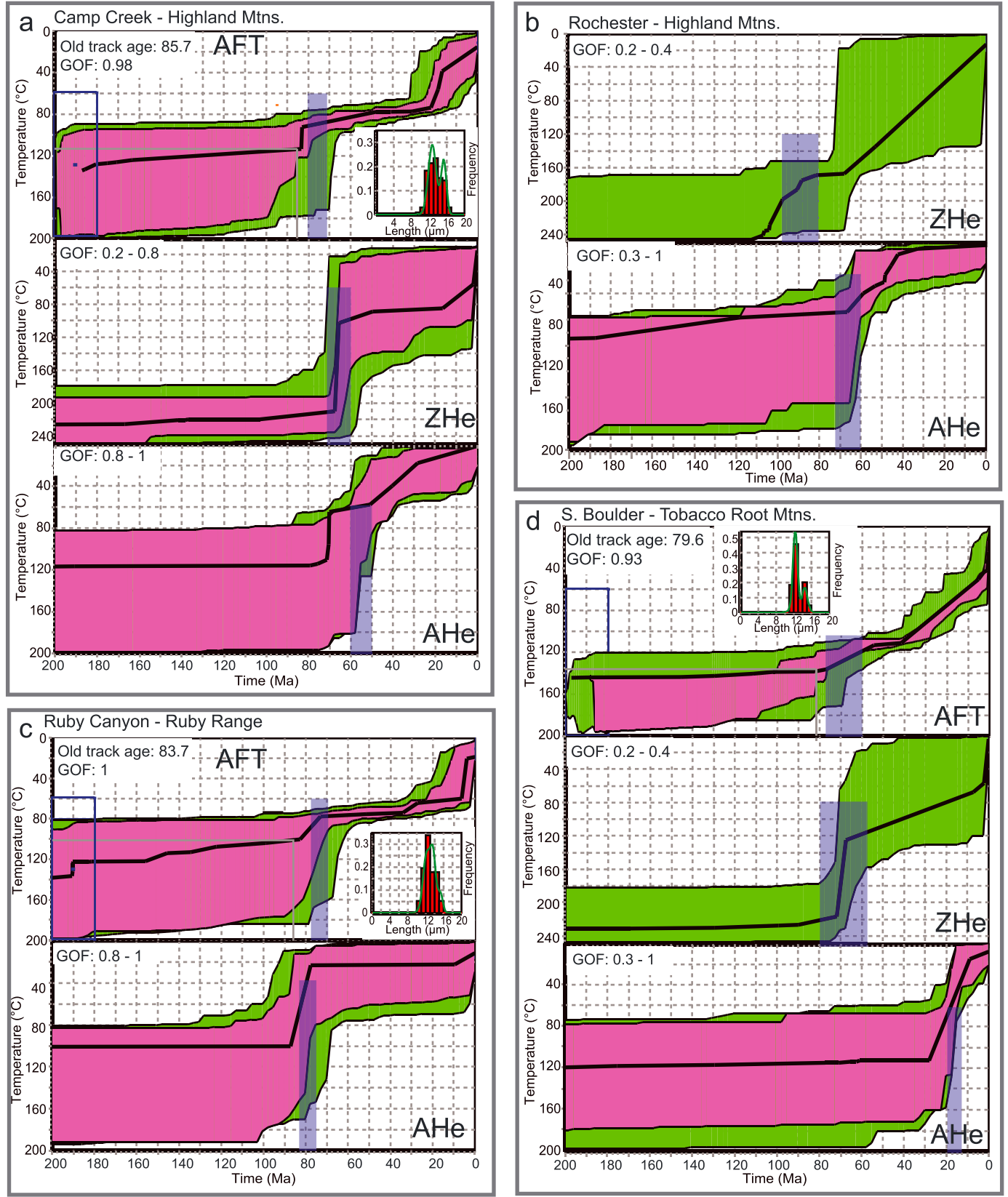

Figure 5. HeFTy inverse modeling results of AFT and (U-Th)/He results for the Camp Creek, Rochester, Ruby Canyon, and S. Boulder samples. AFT and AHe models start with an initial T-window between $60^{\circ} \mathrm{C}-200{ }^{\circ} \mathrm{C}$ between ca. 200-180 and 500-480 Ma, respectively. ZHe models all started with an initial T-window between $180^{\circ} \mathrm{C}-250{ }^{\circ} \mathrm{C}$ and ca. 500-480 Ma. All models ended with a T constrain between ca. $40{ }^{\circ} \mathrm{C}$ and $0{ }^{\circ} \mathrm{C}$ at present. See text and supporting information for additional details.

relationships of apatite (U-Th[-Sm])/He data are shown in Figures S2 and S3. Strong eU age correlations suggest that the samples have spent significant time in the partial retention zone (Flowers et al., 2009; Fox \& Shuster 2014; Gautheron et al., 2009; Willett et al., 2017). Additional details on analytical techniques are provided in the supporting information.

We initially modeled all thermochronometers together; however, in order to obtain acceptable fits, we had to model mean ZHe and AHe ages and compositional data together with AFT data. After this initial exercise, we decided to model all thermochronometers separately using multiple aliquots (for $\mathrm{U}-\mathrm{Th} / \mathrm{He}$ analyses) to demonstrate that AFT and He data independently show a Cretaceous cooling signature. 
Table 2

Modeling Parameters for HeFty Inverse Models in Figures 5 and 6 Following Recommendation From Flowers et al. (2015)

1. Thermochronological data for inverse modeling

\begin{tabular}{|c|c|c|c|}
\hline ZHe data * & number of aliquotes modeled & Data source & Parameters* \\
\hline Camp Creek - & 5 (all) & Table S2 & $4 \mathrm{Ev}$ \\
\hline S Boulder & 5 (all) & Table S2 & $4 \mathrm{Ev}$ \\
\hline Stillwater & $4(\operatorname{Zr~} 1,2,3,4)$ & Table S2 & $4 \mathrm{Ev}$ \\
\hline Rochester & $4(\mathrm{Zr} 2,3,4,5)$ & Table S2 & $4 \mathrm{Ev}$ \\
\hline Rosebud & $3(\mathrm{Zr} 1,2,3)$ & Table S2 & $4 \mathrm{Ev}$ \\
\hline Sphinx & $3(\operatorname{Zr} 2,3,4)$ & Table S2 & $4 \mathrm{Ev}$ \\
\hline AHe data * & number of aliquotes modeled & Data source & \\
\hline Camp Creek & $4(\operatorname{Ap~} 1,2,3,5)$ & Table S3 & $4 \mathrm{Ev}$ \\
\hline S Boulder & $3($ Ap $1,2,3)$ & Table S3 & $4 \mathrm{Ev}$ \\
\hline Ruby Canyon & $3($ Ap $1,2,3)$ & Table S3 & $4 \mathrm{Ev}$ \\
\hline Stillwater & $2(\operatorname{Ap~} 4,5)$ & Table S3 & $4 \mathrm{Ev}$ \\
\hline Rochester & $3($ Ap $1,3,4)$ & Table S3 & $4 \mathrm{Ev}$ \\
\hline Rosebud & $2($ Ap 2,3$)$ & Table S3 & $4 \mathrm{Ev}$ \\
\hline Sphinx & $3(\operatorname{Ap~} 2,4,5)$ & Table S3 & $4 \mathrm{Ev}$ \\
\hline AFT data** & data modeled & Data source & \\
\hline Camp Creek & & Tables S4 and S5 & $4 \mathrm{Ev}$ \\
\hline S Boulder & & Tables S4 and S5 & $4 \mathrm{Ev}$ \\
\hline Ruby Canyon & & Tables S4 and S5 & $4 \mathrm{Ev}$ \\
\hline Stillwater & & Tables S4 and S5 & $4 \mathrm{Ev}$ \\
\hline Clark's Fork & & Tables S4 and S5 & $4 \mathrm{Ev}$ \\
\hline
\end{tabular}

*Initially, all aliquots were modeled together and then subsequently one aliquot at a time was removed until a fit was found.

Different permutations were tried.

**See Table 1

Data treatment, uncertainties, and other relevant constraints

He data:

Treatment: Each zircon and apatite analysis was modeled independently but simultaneously for each sample.

Uncorrected date were corrected for $\sigma$-ejection in HeFTy and stopping distance using Ketcham et al. (2011).

Alpha calculation: redistribution.

Lengths are $C$ axis corrected.

Etching: 5.5. molar nitric acid.

compositional data from $D_{\text {par }}$.

*Parameters used in HeFty.

All data are modeled using the following constraints (Ketcham, 2017).

The number of time the segments between constraints are halved is 4 .

Randomizer style: Episodic mode (E).

Paths between constraints: monotonic variable (v), to allow for both heating and cooling.

2. Additional geological information.

Clark's Fork cgl. are Paleogene requiring the CF4 sample to have been exhumed by then and allowing possible burial after Paleogene time.

3. System and model specific parameters.

ZHe model: Guenthner et al. (2013).

AHe model: RRDAM, Flowers et al. (2009).

FT annealing model: Ketcham et al. (2007).

FT c-axis projection: yes.

Statistical fitting criteria: standard HeFty values number of paths attempted: when number of good paths $=100$ or between 50,000 and 100,000 .

\section{Geochronologic and Thermochronologic Results}

\subsection{Zircon U-Pb Geochronology Results}

All zircon U-Pb geochronologic data presented here are from samples of granitic orthogneiss outcrops or clasts in conglomerates. All samples analyzed show Archean to Paleoproterozoic ages with no differences between rim and core analyses; there is no evidence of Mesozoic or Cenozoic zircon rim growth (Figure S1 and Table S1). The Camp Creek sample from the Highland Mountains produced a concordia (and mean) age of ca. $1798 \mathrm{Ma}$; the Rochester Gulch sample (a clast in the Renova Formation derived from the Highland Mountains) shows a Concordia age of ca. $2812 \mathrm{Ma}$; the Rosebud and the Stillwater samples from the Beartooth Range show concordia and mean ages of ca. 3243 and ca. $2814 \mathrm{Ma}$, respectively (Figure S1 and Table S1). 


\subsection{Low-Temperature Thermochronology Results}

All thermochronological ages are presented in Figure 3 and in the supporting information (Tables S2-S5). The following results are presented in geographical order from west to east. The Camp Creek basement sample from the Highland Mountains produced an AFT central age of $62.0 \pm 4.1 \mathrm{Ma}$ (Tables 1 and S4). ZHe ages for the same sample are between ca. 72 and $61 \mathrm{Ma}$ (Table S2); AHe ages are between ca. 52 and $40 \mathrm{Ma}$ (Table S3). The mid-Cenozoic Renova Formation conglomerate clast (Rochester Gulch), a fragment of gneiss derived from the Highland Mountains, produced an AFT central age of $69.6 \pm 5.4 \mathrm{Ma}$ (Table 1). ZHe ages from the same clast are between ca. 44 and $76 \mathrm{Ma}$ (Figure 3 and Tables S2). No AHe ages are available for this sample.

The South Boulder basement sample from the Tobacco Root Mountains produced an AFT central age of 49.2 \pm 3.7 Ma; ZHe ages are between ca. 80 and $64 \mathrm{Ma}$, and AHe ages are between ca. 27 and $13 \mathrm{Ma}$. The Ruby Canyon basement sample collected from the eastern flank of the Ruby Range produced an AFT central age of 57.2 \pm 3.8 Ma. AHe ages are between ca. 84 and $80 \mathrm{Ma}$. No ZHe ages are available for this sample. The Gravelly Range basement sample from the eastern flank of the Gravelly Range produced an AFT central age of $46.8 \pm 4$ Ma. No (U-Th)/He data are available for this sample. Directly east of the Gravelly Range, the Sphinx basement sample from Archean gneiss in the hanging wall of the Scarface thrust in the Madison Range displays an AFT central age of $18.0 \pm 2.4 \mathrm{Ma}$; ZHe ages are between ca. $125 \mathrm{Ma}$ and $44 \mathrm{Ma}$, and AHe ages are between ca. 84 and 56 Ma. The Maastrichtian Sphinx Conglomerate volcanic clast (Table 1), from the transition between the Livingston Formation and the Sphinx Conglomerate in the Madison Range, yielded an AFT central age of $41.5 \pm 3.2$ Ma. No (U-Th)/He data are available for the Sphinx conglomerate clast.

The Stillwater basement from the northern part of the Beartooth Range has a central AFT age of $56.5 \pm 3.9 \mathrm{Ma}$; ZHe ages are between ca. 83 and $27 \mathrm{Ma}$, and AHe ages are between ca. 191 and $70 \mathrm{Ma}$. AFT central ages from three basement samples from Clark's Fork Canyon on the southeastern margin of the Beartooth Range are between ca. 97 and 73 Ma (Tables 1 and S4). No (U-Th)/He data are available for these samples. We note that previous studies in the Stillwater complex reported variable apatite compositions (high $\mathrm{Cl}$ variability) and ages (Gleadow et al., 2002). Our data from the Stillwater sample do not show anomalous compositional or age variability (Figure 3 and Table S3). The river sand sample collected along the South Boulder River in the Tobacco Root Mountains is best represented by an AFT detrital age range between ca. $\sim 80$ and $40 \mathrm{Ma}$ with a detrital population age of ca. $43 \mathrm{Ma}$ (Figure 4 ). In the northeastern part of the Beartooth Range, the Stillwater River AFT detrital age distribution is characterized by ca. 60and 40-Ma populations. The AFT detrital sample collected along the East Rosebud River on the central eastern flank of the Beartooth Range is best represented by an AFT detrital age range between ca. 110 and $60 \mathrm{Ma}$ (Figure 4).

\subsection{Thermal Modeling Results}

In the following we discuss AFT, ZHe, and AHe inverse modeling results for different Laramide uplifts from west to east. Most AFT samples have a complex (e.g., bimodal) confined-length distribution. No relationships between age or length and $D_{\text {par }}$ are observed (Figure S3), supporting the interpretation that the bimodal length distribution is a result of various times of residence in the PAZ and various degrees of heating and cooling. This means that the central age for these samples represents an integrated (mixed) age and does not represent initiation of cooling but only a minimum age of cooling initiation. Correct interpretation of the thermal history for these samples requires modeling of ages, confined lengths, and $D_{\text {par }}$ data. The inverse modeling results presented are the best results obtained for all samples based on $>50,000$ runs per sample (Table 2). For the AFT system we describe the oldest track age (i.e., the age of oldest fission track that has not fully annealed; Ketcham, 2017) as the oldest cooling signature preserved by the sample and the oldest inflections (within the appropriate T-range for the chosen thermochronometer) in the good fit envelopes (pink), or in the acceptable fit envelopes when good paths are not available, as representative of inception of cooling (Figure 5). We note that any inflection in the inverse modeling envelopes that is older than the oldest track age cannot be resolved. We started all (U-Th)/He models at 500 Ma but show only the interval 200-0 Ma considering that no significant cooling was detected before $200 \mathrm{Ma}$. For details on modeling parameters we refer to Table 2 . 
Inverse modeling results of AFT data of the Camp Creek basement sample from the Highland Mountains (Figure 5a) show an oldest track age of $85.7 \mathrm{Ma}$ (oldest cooling) and early cooling between ca. 80 and $70 \mathrm{Ma}$; later cooling post ca. $25 \mathrm{Ma}$ is also recorded. Inverse modeling results of $\mathrm{ZHe}$ and AHe data indicate cooling between ca. 70 and $60 \mathrm{Ma}$ and between 60 and $50 \mathrm{Ma}$, respectively. We note that ZHe results for this sample are not consistent with AFT results; however, the AFT and AHe results are mutually consistent. The diffusion model used in the ZHe inversion exercise is from Guenthner et al. (2013), which has been shown to be inaccurate in its treatment of radiation damage annealing (Ginster, 2018). Although similar issues may exist for the AHe system (Fox \& Schuster, 2014), the fact that AFT and AHe inverse modeling results are generally consistent with each other suggests that these issues may be less severe for the apatite system. Although the Guenthner et al. (2013) model remains the best available, because of uncertainties raised by Ginster (2018), we place less emphasis on the ZHe results and more on the combined AFT and AHe results.

Inverse modeling results for $\mathrm{ZHe}$ and $\mathrm{AHe}$ data from the Rochester Gulch sample (basement clast in the Renova Formation) from the Highland Mountains show cooling between ca. 98 and 80 Ma and 72 and $60 \mathrm{Ma}$, respectively (Figure 5b). The Ruby Canyon sample from the Ruby Range (Figure 5c) shows an oldest track age of $83.7 \mathrm{Ma}$ and early cooling between ca. 78 and $70 \mathrm{Ma}$; some cooling after ca. $30 \mathrm{Ma}$ is also recorded. The South Boulder sample from the Tobacco Root Mountains (Figure 5d) has an oldest AFT track age of 79.6 Ma; some cooling is recorded by inverse modeling of AFT data between ca. 78 and $60 \mathrm{Ma}$, but most of the cooling occurred post ca. 40 Ma.

ZHe and AHe inverse modeling results show cooling between ca. 80 and $60 \mathrm{Ma}$ and post ca. $20 \mathrm{Ma}$, respectively. ZHe and AHe inverse modeling results from the Sphinx basement sample from the Madison range show cooling between ca. 98 and $78 \mathrm{M}$ and ca. 20 and $8 \mathrm{Ma}$, respectively (Figure 6a). The Stillwater sample from the Beartooth Range (Figure 6b) records an oldest AFT track of 91 Ma and episodic early cooling between ca. 88 and $70 \mathrm{Ma}$; some degree of cooling is also evident after ca. $30 \mathrm{Ma}$. Inverse modeling of ZHe and AHe data shows cooling between ca. 90 and $65 \mathrm{Ma}$ and ca. 100 and $65 \mathrm{Ma}$, respectively. Inverse modeling of $\mathrm{ZHe}$ and $\mathrm{AHe}$ data for the Rosebud sample (Figure 6c) from the Beartooth Range shows cooling between ca. 100 and $88 \mathrm{Ma}$ and 88 and $62 \mathrm{Ma}$, respectively. The Clark's Fork sample (CF4), the lowest sample collected along an age versus elevation profile in Clark's Fork Canyon in the Beartooth Range (Figure 6d), shows an oldest apatite fission track of 123 Ma. Inverse modeling of AFT data from sample CF4 displays (1) cooling through the PAZ during the Early Cretaceous, (2) near-surface temperatures by Late Cretaceous time, (3) reheating in the early-mid Cenozoic, and (4) later cooling in the Miocene (Figure 5). Although we have no AHe ages from sample CF4, this interpretation is required by the bimodal distribution of confined lengths in this sample (Figure 6d). We also note that no good fits are found without a reheating event during the Cenozoic.

\section{Tectonothermal History of Southwestern Montana and Connections to Timing of Deformation, Sedimentation, and Magmatism}

Our zircon U-Pb ages from southwestern Montana show Archean to Paleoproterozoic ages and are generally in agreement with ${ }^{40} \mathrm{Ar} /{ }^{39} \mathrm{Ar}$ ages of hornblende grains from the Tobacco Root Mountains showing Proterozoic ages (Brady et al., 2004). No Cretaceous or Cenozoic rims were found in the analyzed samples.

Thermochronological data of basement samples in southwestern Montana record significant cooling prior to $80 \mathrm{Ma}$ and as early as ca. $120 \mathrm{Ma}$ (Beartooth and Ruby Ranges). Early Cenozoic cooling was minor; some reheating sometime between ca. 55 and $25 \mathrm{Ma}$, and subsequent cooling, occurred in the southern Beartooth Range (AFT data from Clark's Fork sample; Figure 6d).

The timing of initiation of significant Cretaceous cooling recorded by low-temperature thermochronology often predates the peak of magmatic activity in the region. Although the timing of magmatism in Montana is complex (du Bray et al., 2012; Gaschnig et al., 2010; Harlan et al., 1996; Kellogg \& Harlan, 1997), peak activity can be broadly bracketed between ca. 80 and 64 Ma (Lageson et al., 2001; Lund et al., 2002) and eastward migration of the magmatic front occurred between ca. 80 and 55 Ma (Figure 1; Constenius et al., 2003).

Although these events may have affected our thermochronological signal, several samples from this study preserve an earlier record of cooling. Coupled with the fact that no evidence of magmatic/metamorphic 

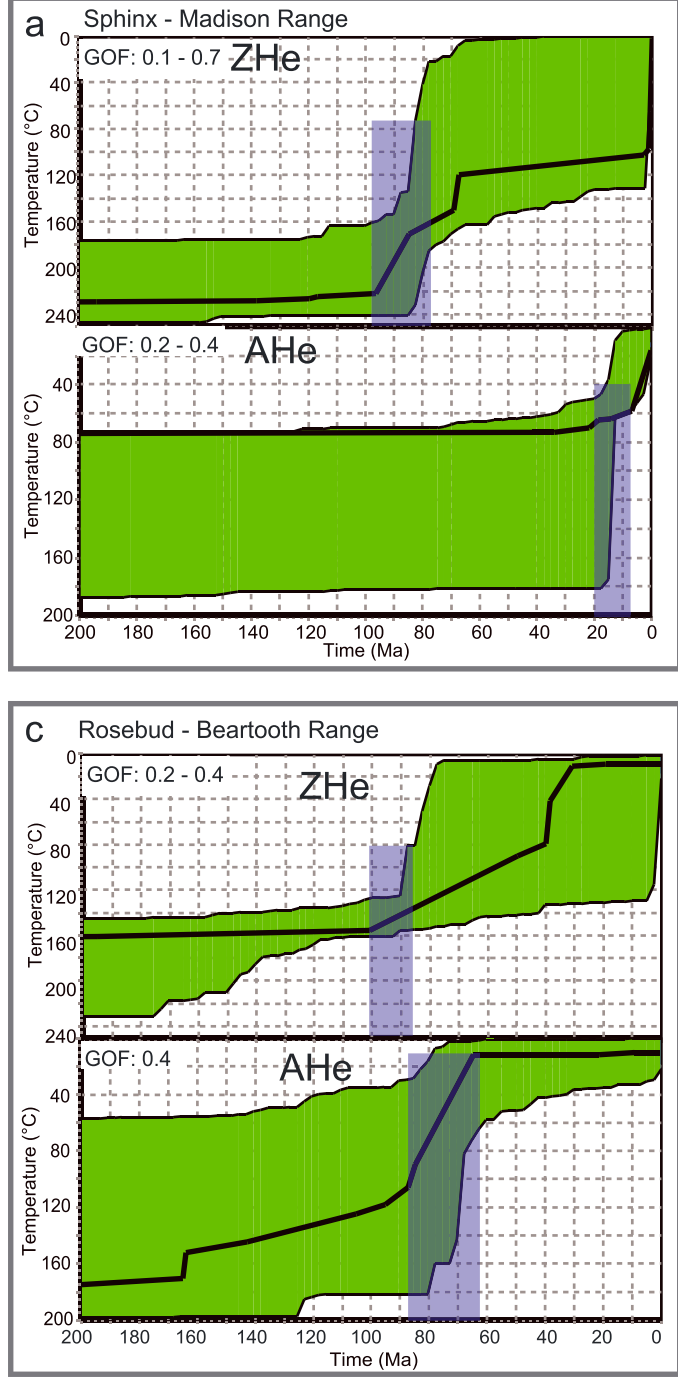
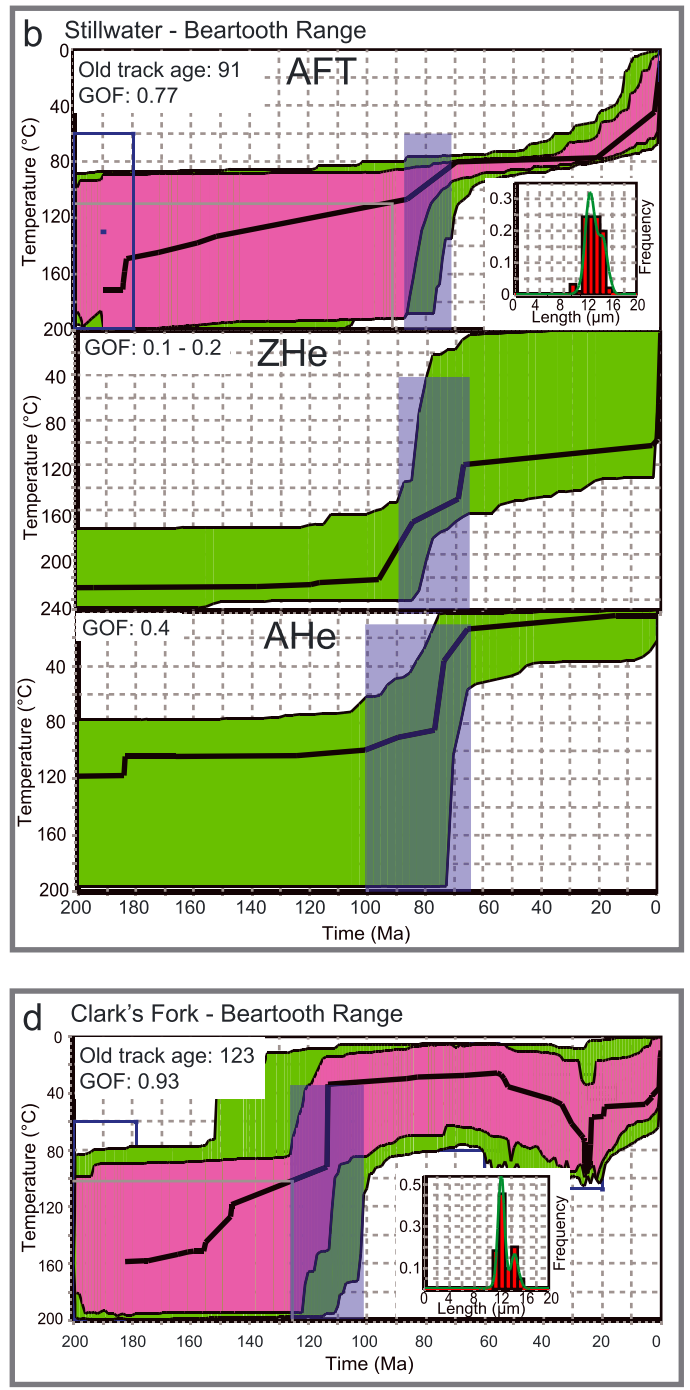

Figure 6. HeFTy inverse modeling results of AFT and (U-Th)/He results for the Madison, Stillwater, Rosebud, and Clark's Fork samples. Modeling constrains are the same as samples in Figure 5. Other independent geological constraints were applied for sample CF4; for this sample we infer a location close to the surface during the Paleocene because the nearby syntectonic Paleocene Beartooth Conglomerate was derived from the section of rocks that we sampled (DeCelles et al., 1991); these same rocks must have been reheated, at least partially, due to burial by the conglomerate. When the two initial t-T constraints were not enough to produce acceptable results, larger t-T boxes were applied to allow the model a higher degree of freedom.GOF: ood of fitness (between model age and measured age). Green areas: acceptable-fit paths, pink areas: good-fit paths; black lines: best fit paths. Gray lines: time-T corresponding to the oldest track age (the age of the oldest fission track to survive annealing in the model simulation).

overprinting is recorded by $\mathrm{U}-\mathrm{Pb}$ geochronology of zircon rims, this suggests that the Cretaceous cooling recorded by low- $\mathrm{T}$ thermochronology represents deformation-driven exhumation rather than cooling following Cretaceous magmatism.

Magmatic overprinting (contact metamorphism) suggested to have occurred in the Tobacco Root Mountains at ca. $75 \mathrm{Ma}$ based on a few ${ }^{40} \mathrm{Ar} /{ }^{39} \mathrm{Ar}$ hornblende ages (Brady et al., 2004; Figure 2) could explain some of the cooling recorded by the South Boulder samples, although both AFT and ZHe data indicate that cooling started as early as $80 \mathrm{Ma}$ (Figure 5d). Interestingly, no significant cooling is recorded by AFT between ca. 60 and $50 \mathrm{Ma}$, which is the main timing of cooling recorded by AFT in the Wind River Range in Wyoming (Stevens et al., 2016).

Early to mid-Cretaceous inception of Laramide deformation and exhumation in southwestern Montana is generally older than the timing of peak magmatism in the region but is coeval with timing of exhumation of the Idaho shear zone (ISZ; Braudy et al., 2017). The ISZ has been associated with contractional 
deformation and northeast-southwest directed convergence between the Insular superterrane and North America (Giorgis et al., 2007, 2017). Exhumation of Laramide ranges during Early to mid-Cretaceous time has been suggested on the basis of complex isopach and paleocurrent patterns in Aptian-Albian (ca. 120-95 Ma) fluviolacustrine deposits (Schwartz \& DeCelles, 1988; Suttner et al., 1981); the basal conglomerate of the Kootenai Formation records drainage reorganization that was originally interpreted to be related to intraforeland uplift and erosion of the Tobacco Root, Madison-Gravelly, and Beartooth Laramide blocks (DeCelles, 1986; Schwartz \& DeCelles, 1988). An alternative explanation for the early Cretaceous paleogeographic complexity of fluvial systems in southwestern Montana is the development of a broken flexural forebulge in the region (DeCelles, 2004). Still unaccounted for is the volume of sediment expected to have been eroded off of the early Laramide uplifts in Montana. As mentioned earlier, where synorogenic conglomerates are preserved along the flanks of Laramide structures, they generally postdate the ca. 100-80-Ma cooling/exhumation signal recorded in our data, as well as substantial amounts of structural deformation (Ryder \& Scholten, 1973; DeCelles et al., 1987, 1991; Haley \& Perry, 1991; Hoy \& Ridgway, 1997). One possibility is that early exhumation of Montana Laramide uplifts entailed recycling of 1-2-km thicknesses of generally fine-grained distal foreland basin deposits off the tops of growing uplifts and bypassing into distal depocenters, rather than accumulating adjacent to growing uplifts (DeCelles et al., 1991). This, combined with the fact that cooling during rock uplift may predate erosion, could account for the magnitude of cooling recorded by our samples (ter Voorde et al., 2004).

Some reheating during the Paleogene may be related to late magmatism in the Idaho and Boulder batholiths (Gaschnig et al., 2010; Lund et al., 2002) or to widespread Eocene magmatic activity in western Montana, including the Absaroka volcanic field (Chadwick, 1970; Feeley \& Cosca, 2003; Hearn, 1989; Smedes \& Prostka, 1972). Late Eocene-Oligocene heating in the Beartooth Range may also be associated with Absaroka volcanic activity and/or slab rollback (e.g., Constenius et al., 2003; Schwartz \& Schwartz, 2013). A reheating event in the eastern Beartooth Range (Clark's Fork sample) could also be related to deposition of thick Paleogene synorogenic conglomerate along the eastern flank of the range (DeCelles et al., 1991). Cooling during the Neogene is recorded by AFT central ages from the Sphinx and Renova conglomerate samples (Table 1) obtained from the Madison Range and Highland Mountains, respectively. Neogene cooling is also recorded from inverse modeling of AFT samples from the Beartooth Range and Highland Mountains. Neogene cooling is consistent with Basin-and-Range extension and exhumation (Parsons, 1995).

Detrital AFT data from rivers draining the Beartooth Range and Tobacco Root Mountains show main age populations between ca. 39 and $75 \mathrm{Ma}$ with an older component at $176 \mathrm{Ma}$ (Figure 4). Although detrital ages are assumed to mirror mean ages of basement samples from the ranges they are derived from, the detrital ages are subject to the same ambiguities that accompany basement samples in terms of complex thermal histories; therefore, they only represent a minimum age of exhumation. This is evident by the detrital populations recorded by the Stillwater, Rosebud, and South Boulder Rivers draining the northern and central Beartooth Range and Tobacco Root Mountains, which are generally younger than the main cooling ages of the basement they are derived from (Figure 5).

Because the exhumation history in Wyoming seems to record events that long postdate initial Laramide deformation (Peyton \& Carrapa, 2013; Peyton et al., 2012), the earlier history associated with inception of thick-skinned deformation and possible flat-slab subduction may have been overprinted by younger events in Wyoming. Deformation could have begun before the onset of thermally recorded exhumation; thus, thermochronological ages in Wyoming may only provide a minimum age for the beginning of Laramide deformation. Our data from Montana preserve an earlier record of cooling, which could reflect a variety of processes including fluid flow, postmagmatic cooling, and deformation-driven exhumation. When combined with other data from the region, our results suggest that the onset of Laramide-style deformation may have been earliest in southwestern Montana.

If the timing of magmatic sweep between ca. 80 and $55 \mathrm{Ma}$ (Figure 1) in western Montana (Constenius et al., 2003) faithfully represents the timing of slab shallowing, then thermochronological and geochronological data from this study suggest that cooling and exhumation of at least some thick-skinned structures in Montana predated flat-slab subduction beneath this region. The onset of basement deformation could have propagated through the region ahead of the flat slab (e.g., Kulik \& Schmidt, 1988; Gutscher, 2000), or 
magmatism associated with slab flattening is only incompletely represented by surface exposures (Snyder et al., 1976). Alternatively, thick-skinned deformation in Montana is not related to slab shallowing or flatslab subduction and, instead, may be the result of (1) deformation associated with end loading of North American lithosphere (or its deep keel) during Farallon-North America plate convergence (Schmidt \& Perry, 1988; Erslev, 2005; DeCelles, 2004; Behr \& Smith, 2016; Yonkee \& Weil, 2015) or (2) lateral injection of ductile lower crust from beneath the Cordilleran fold-thrust belt (McQuarrie \& Chase, 2000). Although these ideas are consistent with some data sets, it is nevertheless difficult to explain the inboard magmatic sweep and many aspects of Laramide strain distribution with models that do not involve some component of flat-slab subduction (Bird, 1984, 1998; Coney \& Reynolds, 1977; Constenius et al., 2003).

\section{Discussion}

Obtaining good model fits for all of the thermochronological data modeled together was challenging, and although the precise timing of early cooling varies among samples, the general pattern is more important than specific model outputs. The fact that all thermochronometers independently record various degrees of cooling during the Middle to Upper Cretaceous suggests that regardless of individual model limitations, the early cooling signal is significant. Combined with evidence of Early to mid-Cretaceous foreland basin drainage complexity (Schwartz \& DeCelles, 1988), this suggests that our early cooling signal represents tectonically driven exhumation.

The record of the Laramide orogenic event consists of three main signals: (1) an increase in wavelength and eastward shift in the locus of Late Cretaceous subsidence (Cross \& Pilger, 1978); (2) nearly extinguished magmatic activity within the linear Cordilleran magmatic arc near the west coast over the latitudal span of the Laramide region, accompanied by inboard migration of much reduced magmatism (Coney \& Reynolds, 1977; Constenius et al., 2003; Lipman et al., 1971); and (3) the development of the basementinvolved Laramide uplifts and intervening basins (Dickinson et al., 1988; Dickinson \& Snyder, 1978; Lawton, 2008). Each of these signals records a different aspect of the Laramide event, including the insertion of the flat slab beneath the Laramide region (Liu et al., 2010), the disruption of the magmatic plumbing system beneath the arc (Coney \& Reynolds, 1977; Constenius et al., 2003; Lipman et al., 1971), and the transfer of stresses from the subducting flat slab to the overlying North American Plate (Behr \& Smith, 2016; Bird, 1984; Dickinson \& Snyder, 1978; Erslev, 1993; Jones et al., 2011). Thermochronological data, such as those presented here, track the timing of cooling and exhumation of individual Laramide uplifts and therefore speak only to the last of these processes. Accordingly, our results suggest that Laramide deformation and range exhumation were well underway in southwestern Montana by ca. $80 \mathrm{Ma}$, up to $10 \mathrm{Myr}$ earlier than suggested by existing data from Laramide uplifts of Wyoming. Although more data are needed from Wyoming, existing data are consistent with models proposing enhanced coupling between the flat slab and the overriding plate to transmit compressive stresses cratonward into mechanically heterogeneous basement crust of the upper plate, possibly beyond the limits of the flat slab (e.g., Bird, 1984, 1988; Kulik \& Schmidt, 1988; Gutscher, 2000; Jones et al., 2011).

A general model for the Laramide flat-slab event involving a combination of initial slab shallowing owing to increased convergence rate, followed by slab flattening in response to interaction with the Archean craton lithospheric keel (Jones et al., 2011), with or without subduction of a Shatsky conjugate (Liu et al., 2010), would seem to satisfy most of the existing data from thermochronology and basin evolution. However, the Laramide uplifts of Montana present some difficulties for recent geodynamic models that project a narrow zone of shallow flat-slab subduction from the Mojave Desert region into central Wyoming along a northnortheastward trajectory (e.g., Axen et al., 2018; Jones et al., 2011; Liu et al., 2010). Refined models might include the effects of a spatially less restricted Shatsky conjugate moving along a trajectory more eastward than northward; a zone of somewhat deeper, but still flat, subducting Farallon lithosphere to the north of the zone of shallowest subduction (e.g., Saleeby, 2003); and a cratonic lithospheric root that extends farther north below the Archean crust of western Montana. Basement arches in central and northern central Montana (e.g., Little Belt Mountains, Little Rocky Mountains, and Bowdoin Dome; Vuke et al., 2007) present additional challenges for current notions of the location of the Farallon flat slab.

Previous studies of uplift, basin subsidence, and erosional histories of the Laramide in Wyoming indicate mostly early Cenozoic ages (e.g., Peyton et al., 2012; Stevens et al., 2016); these relatively young ages 
may represent thermal processes related to westward roll-back of the subducting slab (Fan \& Carrapa, 2014) or accretion of Shatsky conjugate depleted mantle lithosphere beneath Wyoming and the associated upper crustal deformation and subsequent removal (Humphreys et al., 2015; Stevens et al., 2016). Westward to southwestward migration of magmatism in the mid-Cenozoic is consistent with the history of the stress field (Bird, 2002) and can be explained by westward migration of the Farallon plate hingeline and falling away of the slab (referred to as slab rollback; Best et al., 2009; Coney \& Reynolds, 1977; Constenius, 1996; Dickinson \& Snyder, 1978). Accompanying southwestward slab rollback was a pattern of deformation and exhumation across the Laramide region, possibly related to removal of dense mantle lithosphere and/or asthenospheric upwelling (Constenius, 1996; Copeland et al., 2017; Fan \& Carrapa, 2014; Humphreys, 2009; Liu \& Gurnis, 2010).

The Sierras Pampeanas of western Argentina provide a modern analog to the Laramide orogenic event (Jordan \& Allmendinger, 1986). If we assume that the Laramide flat slab in southwestern Montana transitioned northward to more normal subduction, as suggested by continuous magmatic activity in the Idaho batholith and the magmatic arc along tectonic strike to the north (Gaschnig et al., 2017; Gehrels et al., 2009), the configuration of the slab was remarkably similar to the Pampean flat slab, which transitions southward into a normal-angle subducting slab at ca. $32-33^{\circ} \mathrm{S}$ (Wagner et al., 2006; Porter et al., 2012). The peripheral Laramide uplifts in north central Montana, western South Dakota, and Colorado are located hundreds of kilometers inboard of the probable limit of flat-slab subduction (Jones et al., 2011; Liu et al., 2010), analogous to the farthest inboard Sierras Pampeanas uplifts (Wagner et al., 2006). Perhaps the anomalous Late Cretaceous to early Cenozoic (ca. 80-64 Ma) magmatic activity in southwestern Montana is similar to melting associated with clockwise asthenospheric flow around the southeast facing corner of the Pampean flat slab (Wagner et al., 2006). In Montana, asthenospheric flow would have been counterclockwise around a northeast facing slab corner.

\section{Conclusions}

1. Southwestern Montana represents a significant part of the Laramide foreland province that is underrepresented in geodynamic models for the Laramide orogenic event.

2. Southwestern Montana preserves a complete record of early Laramide exhumation as early as ca. $100 \mathrm{Ma}$, along with subsequent Eocene to early Miocene magmatic heating and/or burial (ca. 50-20 Ma) and post ca. 25 Ma cooling and exhumation associated with Basin-and-Range tectonics. In the context of the existing evidence for eastward sweeping magmatism between ca. 80 and $55 \mathrm{Ma}$, our data suggest that at least some exhumation of thick-skinned structure in Montana and northwestern Wyoming took place cratonward from the area of flat-slab subduction, possibly due to stress propagation from enhanced intraplate coupling over the flat-slab region.

3. Laramide deformation, exhumation, and sedimentation in southwestern Montana initiated earlier in comparison to other parts of the Laramide foreland to the south. The greater areal distribution and earlier timing of northern Laramide deformation provides new constraints on the shape, timing, and path of entry of the flat slab (with or without a Shatsky conjugate plateau) beneath western North America, as well as its subsequent removal.

Acknowledgments We thank Kurt Constenius for informative discussions on the geology of Montana; Peter Bird, Craig Jones, and two anonymous reviewers for careful and constructive reviews; and Editor Uri ten Brink for reviewing and handling this manuscript. Mark Pecha and George Gehrels helped with zircon $\mathrm{U}-\mathrm{Pb}$ analyses and data interpretation and Peter Reiners helped with (U-Th)/ He analyses. S. Duke assisted with fieldwork. Data supporting the conclusions are available in the supporting information. Partial funding was provided by NSF-Tectonics EAR1524151. All supporting data can be found online in the supporting information.
4. Additional thermochronological studies from the northern Laramide region of Montana and Wyoming are essential to constrain the timing and trends of exhumation related to Laramide deformation and to help test kinematic/tectonic models of thick-skinned deformation and flat-slab subduction.

\section{References}

Amato, J. M., Mack, G. H., Jonell, T. N., Seager, W. R., \& Upchurch, G. R. (2017). Onset of the Laramide orogeny and associated magmatism in southern New Mexico based on U-Pb geochronology. Geological Society of America Bulletin, B31629.1. https://doi.org/10.1130/ B31629.1

Axen, G. J., van Wijk, J. W., \& Currie, C. A. (2018). Basal continental mantle lithosphere displaced by flat-slab subduction. Nature Geoscience, 11(12), 961-964. https://doi.org/10.1038/s41561-018-0263-9

Behr, W. M., \& Smith, D. (2016). Deformation in the mantle wedge associated with Laramide flat-slab subduction. Geochemistry, Geophysics, Geosystems, 17, 2643-2660. https://doi.org/10.1002/2016GC006361

Best, M. G., Barr, D. L., Christainsen, E. H., Gronme, C. S., Deino, A. L., \& Tingey, D. G. (2009). The Great Basin altiplano during the middle Cenozoic ignimbrite flare up: Insights from volcanic rocks. International Geological Review, 51, 580-633.

Bird, P. (1984). Laramide crustal thickening event in the Rocky Mountain foreland and Great Plains. Tectonics, 3(7), 741-758. https://doi. org/10.1029/TC003i007p00741 
Bird, P. (1988). Formation of the Rocky Mountains, Western United States: A continuum computer model. Science, 239(4847), 1501-1507. https://doi.org/10.1126/science.239.4847.1501

Bird, P. (1998). Kinematic history of the Laramide orogeny in latitudes 35-49 N, western United States. Tectonics, 17(5), 780-801. https:// doi.org/10.1029/98TC02698

Bird, P. (2002). Stress direction history of the western United States and Mexico since 85 Ma. , Tectonics, 21 (3), 5-1 -5-12

Blackstone, D. L. (1986). Structural geology—Northwest margin (pp. 125-135). Park County, Wyoming and Carbon County, Montana, Yellowstone-Bighorn Research Association, Field Conference, Guidebook: Bighorn basin.

Brady, J. B., Kovaric, D. N., Cheney, J. T., Jacob, L. J., \& King, J. T. (2004). ${ }^{40} \mathrm{Ar} /{ }^{39} \mathrm{Ar}$ ages of metamorphic rocks from the Tobacco Root Mountains region, Montana. In J. B. Brady, H. R. Burger, J. T. Cheney, \& T. A. Harms (Eds.), Precambrian geology of the Tobacco Root MountainsSpecial Paper (Vol. 377, pp. 131-149). Montana: Boulder, Colorado: Geological Society of America. https://doi.org/10.1130/08137-2377-9.131

Braudy, N., Gaschnig, R. M., Wilford, D., Vervoort, J. D., Nelson, C. L., Davidson, C., et al. (2017). Timing and deformation conditions of the western Idaho shear zone, West Mountain, west-central Idaho. Lithosphere, 9(2), 157-183. https://doi.org/10.1130/L519.1

Brown, W. G. (1988). Deformational style of Laramide uplifts in the Wyoming foreland. Geological Society of America Memoirs, 171, 1-26. https://doi.org/10.1130/MEM171-p1

Cerveny, P. F., \& Steidtmann, J. R. (1993). Fission track thermochronology of the Wind River Range, Wyoming: Evidence for timing and magnitude of Laramide exhumation. Tectonics, 12(1), 77-91. https://doi.org/10.1029/92TC01567

Chadwick, R. A. (1970). Belts of eruptive centers in the Absaroka-Gallatin volcanic province, Wyoming-Montana. Geological Society of America Bulletin, 81(1), 267-274. https://doi.org/10.1130/0016-7606(1970)81[267:BOECIT]2.0.CO;2

Chapin, C. E., \& Cather, S. M. (1983). Eocene tectonics and sedimentation in the Colorado Plateau-Rocky Mountain area. In J. D. Lowell \& R. Gries (Eds.), Rocky Mountain Foreland Basins and Uplifts (pp. 33-56). Denver, Colorado: Rocky Mountain Association of Geologists.

Clinkscales, C. A., \& Lawton, T. F. (2015). Timing of Late Cretaceous shortening and basin development, Little Hatchet Mountains, southwestern New Mexico, USA-Implications for regional Laramide tectonics. Basin Research, 27(4), 453-472. https://doi.org/ $10.1111 /$ bre. 12083

Colpron, M., Nelson, J. L., \& Murphy, D. C. (2007). Northern Cordilleran terranes and their interactions through time. GSA Today, 17(4/5), 4-11.

Coney, P. J., \& Reynolds, S. J. (1977). Cordilleran benioff zones. Nature, 270(5636), 403-406. https://doi.org/10.1038/270403a0

Constenius, K., Esse, R. P., \& Layer, P. W. (2003). Extensional collapse of the Charleston-Nebo Salient and its relationship to space-time variations in Cordilleran Orogenic Belt tectonism and continental stratigraphy. In R. G. Raynolds \& R. M. Flores (Eds.), Cenozoic systems of the Rocky Mountain Region Denver (pp. 303-353). Denver, CO: Rocky Mountain SEPM.

Constenius, K. N. (1996). Late Paleogene extensional collapse of the Cordilleran foreland fold and thrust belt. Geological Society of America Bulletin, 108(1), 20-39.

Copeland, P., Currie, C. A., Lawton, T. F., \& Murphy, M. A. (2017). Location, location, location: The variable lifespan of the Laramide orogeny. Geology, 45(3), 223-226. https://doi.org/10.1130/G38810.1

Crews, S. G., \& Ethridge, F. G. (1993). Laramide tectonics and humid alluvial fan sedimentation, NE Uinta uplift, Utah and Wyoming. Journal of Sedimentary Petrology, 63, 420-436.

Cross, T. A. (2009). Tectonic controls of foreland basin subsidence and Laramide style deformation, western United States. In P. A. Allen \& P. Homewood (Eds.), Foreland basins: Special Publication of the International Association of Sedimentologists (Vol. 8, pp. 15-39). Hoboken, NJ: Wiley-Blackwell. https://doi.org/10.1002/9781444303810.ch1

Cross, T. A., \& Pilger, R. H. Jr. (1978). Tectonic controls of Late Cretaceous sedimentation, Western Interior. Nature, 274(5672), 653-657. https://doi.org/10.1038/274653a0

Crowley, R. D., Reiners, P. W., Reuter, J. M., \& Kaye, G. D. (2002). Laramide exhumation of the Bighorn Mountains, Wyoming: An apatite (U-Th)/He thermochronology study. Geology, 30(1), 27-30. https://doi.org/10.1130/0091-7613(2002)030<0027:LEOTBM>2.0. $\mathrm{CO} ; 2$

DeCelles, P. G. (1986). Sedimentation in a tectonically partitioned, nonmarine foreland basin: The Lower Cretaceous Kootenai Formation, southwestern Montana. Geological Society of America Bulletin, 97(8), 911-931. https://doi.org/10.1130/0016-7606(1986)97<911: SIATPN $>2.0 . \mathrm{CO} ; 2$

DeCelles, P. G. (2004). Late Jurassic to Eocene evolution of the Cordilleran thrust belt and foreland basin system, western USA. American Journal of Science, 304(2), 105-168. https://doi.org/10.2475/ajs.304.2.105

DeCelles, P. G., Gray, M. B., Ridgway, K. D., Cole, R. B., Srivastava, P., Pequera, N., \& Pivnik, D. A. (1991). Kinematic history of foreland uplift from Paleocene synorogenic conglomerate, Beartooth Range, Wyoming and Montana. Geological Society of America Bulletin, 103(11), 1458-1475. https://doi.org/10.1130/0016-7606(1991)103,1458:KHOAFU.2.3.CO;2

DeCelles, P. G., Tolson, R. B., Graham, S. A., Smith, G. A., Ingersoll, R. V., White, J., \& Bargar, E. (1987). Laramide thrust-generated alluvial-fan sedimentation, Sphinx Conglomerate, southwestern Montana. AAPG Bulletin, 71(2), 135-155.

Devlin, W. J., Rudolph, K. W., Shaw, C. A., \& Ehman, K. D. (1993). The effect of tectonic and eustatic cycles on accommodation and sequence-Stratigraphic framework in the Upper Cretaceous foreland basin of southwestern Wyoming. International Association of Sedimentologists. Special Publication, 18, 501-520.

Dickinson, W. R. (2004). Evolution of the North American Cordillera. Annual Review of Earth and Planetary Sciences, 32(1), 13-45. https:// doi.org/10.1146/annurev.earth.32.101802.120257

Dickinson, W. R., Klute, M. A., Hayes, M. J., Janecke, S. U., Lundin, E. R., McKittrick, M. A., \& Olivares, M. D. (1988). Paleogeographic and paleotectonic setting of Laramide sedimentary basins in the central Rocky Mountain region. Geological Society of America Bulletin, 100(7), 1023-1039. https://doi.org/10.1130/0016-7606(1988)100<1023:PAPSOL >2.3.CO;2

Dickinson, W. R., \& Snyder, W. S. (1978). Plate tectonics of the Laramide orogeny. Geological Society of America Memoirs, 151, 355-366. https://doi.org/10.1130/MEM151-p355

Donelick, R. A. (1993). Method of fission track analysis utilizing bulk chemical etching of apatite, U.S. Patent No.5,267,274.

Donelick, R. A., O'Sullivan, P. B., \& Ketcham, R. A. (2005). Apatite fission-track analysis. Reviews in Mineralogy and Geochemistry, 58(1), 49-94. https://doi.org/10.2138/rmg.2005.58.3

du Bray, A., Aleinikoff, J. N., \& Lund, K. (2012). Synthesis of petrographic, geochemical, and isotopic data for the Boulder Batholith. USGS: Southwest Montana. Professional Paper 1793

du Bray, E. A., \& Harlan, S. H. (1998). Geology, Age, and Tectonic Setting of the Cretaceous Sliderock Mountain Volcano, Montana, U.S Geological Survey Professional Paper, 1602. 
Erslev, E. A. (1991). Trishear fault-propagation folding. Geology, 19(6), 617-620. https://doi.org/10.1130/0091-7613(1991)019<0617: $\mathrm{TFPF}>2.3 . \mathrm{CO} ; 2$

Erslev, E. A. (1993). Thrusts, backthrusts and detachment of Laramide foreland arches. In C. J. Schmidt, R. Chase, \& E. A. Erslev (Eds.), Laramide basement deformation in the Rocky Mountain foreland of the western United StatesGeological Society of America Special Paper (Vol. 280, pp. 125-146). https://doi.org/10.1130/SPE280-p125

Erslev, E. A. (2005). 2D Laramide geometries and kinematics of the Rocky Mountains, western U.S.A. In The Rocky Mountain Region: An evolving lithosphere, Geophysical Monograph Series (Vol. 154, pp. 1-14). Washington, DC: American Geophysical Union. https://doi.org/ 10.1029/154GM0

Erslev, E. A., \& Koenig, N. V. (2009). Three-dimensional kinematics of Laramide, basement-involved Rocky Mountain deformation, USA: Insights from minor faults and GIS-enhanced structure maps. Memoir - Geological Society of America, 204, 125-150. https://doi.org/ $10.1130 / 2009.1204(06)$

Faccenna, O., Oncken, O., Holt, A. F., \& Becker, T. W. (2017). Initiation of the Andean orogeny by lower mantle subduction. Earth and Planetary Science Letters, 463, 189-201. https://doi.org/10.1016/j.epsl.2017.01.041

Fan, M., \& Carrapa, B. (2014). Late Cretaceous-early Eocene Laramide uplift, exhumation, and basin subsidence in Wyoming: Crustal responses to flat slab subduction. Tectonics, 33, 509-529. https://doi.org/10.1002/2012TC003221

Fan, M., DeCelles, P. G., Gehrels, G. E., Dettman, D. L., Quade, J., \& Peyton, S. L. (2011). Sedimentology, detrital zircon geochronology, and stable isotope geochemistry of the lower Eocene strata in the Wind River Basin, cCentral Wyoming. Geological Society of America Bulletin, 123(5-6), 979-996. https://doi.org/10.1130/B30235.1

Farley, K. A. (2002). (U-Th)/He Dating: Techniques, calibrations, and applications. In Noble gases in Geochemistry and Cosmochemistry. Reviews in Mineralogy and Geochemistry. No. 47 (pp. 819-844). Washington, DC: Mineralogical Society of America.

Farley, K. A., Wolf, R. W., \& Silver, L. T. (1996). The effects of long alpha-stopping distances on (U-Th)/He ages. Geochim Cosmochim Acta, $60,4223-4229$.

Feeley, T. C., \& Cosca, M. (2003). Time vs. composition trends of magmatism at Sunlight volcano, Absaroka volcanic province, Wyoming Geological Society of America Bulletin, 115(6), 714-728. https://doi.org/10.1130/0016-7606(2003)115<0714:TVCTOM>2.0.CO;2

Flowers, R. M., Farley, K. A., \& Ketcham, R. A. (2015). A reporting protocol for thermochronologic modeling illustrated with data from the Grand Canyon. Earth and Planetary Science Letters, 432, 425-435. https://doi.org/10.1016/j.epsl.2015.09.053

Flowers, R. M., Ketcham, R. A., Shuster, D. L., \& Farley, K. A. (2009). Apatite (U-Th)/He thermochronometry using a radiation damage accumulation and annealing model. Geochimica et Cosmochimica Acta, 73(8), 2347-2365. https://doi.org/10.1016/j.gca.2009.01.015

Flueckinger, L. A. (1970). Stratigraphy, petrography and origin of Tertiary sediments off the front of the Beartooth Mountains, MontanaWyoming [Ph.D. dissertation], University Park, Pennsylvania, Pennsylvania State University, 249 p.

Fornash, K. F., Patchett, P. J., Gehrels, G. E., \& Spencer, J. E. (2013). Evolution of granitoids in the Catalina metamorphic core complex, southeastern Arizona: U-Pb, Nd, and Hf isotopic constraints. Contributions to Mineralogy and Petrology, 165(6), 1295-1310. https://doi. org/10.1007/s00410-013-0859-4

Foster, D. A., Mueller, A., Heatherington, A., Gifford, J. N., \& Kalakay, T. J. (2012). Lu-Hf systematics of magmatic zircons reveal a Proterozoic crustal boundary under the Cretaceous Pioneer batholith, Montana. Lithos, 142-143, 216-225. https://doi.org/10.1016/j. lithos.2012.03.005

Foster, D., Mueller, P., Heatherington, A., Vogl, J., Meert, J., Lewis, R., \& Wooden, J. (2002). Configuration of the 2.0-1.6 Ga accretionary margin of the NW Wyoming Province: Implications for Proterozoic continental reconstructions. Geological Society of America Abstracts with Programs, 34, A-559.

Fox, M., \& Shuster, D. L. (2014). The influence of burial heating on the (U-Th)/He system in apatite: Grand Canyon case study. Earth and Planetary Science Letters, 397, 174-183. https://doi.org/10.1016/j.epsl.2014.04.041

Garihan, J. M., Schmidt, C. J., Young, S. W., \& Williams, M. A. (1983). Recurrent movement history of the Bismark-Spanish Peaks-Gardiner fault system, southwest Montana. In J. D. Lowell \& R. Gries (Eds.), Rocky Mountain foreland basins and uplifts (pp. 295-314). Denver, Colorado: Rocky Mountain Association of Geologists.

Gaschnig, R. M., Vervoort, J. D., Lewis, R., \& McClelland, W. (2010). Migrating magmatism in the northern US Cordillera: In situ U-Pb geochronology of the Idaho batholith. Contributions to Mineralogy and Petrology, 159(6), 863-883. https://doi.org/10.1007/s00410-009$0459-5$

Gaschnig, R. M., Vervoort, J. D., Tikoff, B., \& Lewis, R. S. (2017). Construction and preservation of batholiths in the northern U.S. Cordillera. Lithosphere, 9, 315-324.

Gautheron, C., Tassan-Got, L., Barbarand, J., \& Pagel, M. (2009). Effect of alpha-damage annealing on apatite (U-Th)/He thermochronology. Chemical Geology, 266, 157-170.

Gehrels, G., Rusmore, M., Woodsworth, G., Crawford, M., Andronicos, C., Hollister, L., et al. (2009). U-Th-Pb geochronology of the Coast Mountains Batholith in north-coastal British Columbia: Constraints on age, petrogenesis, and tectonic evolution. Geological Society of America Bulletin, 121, 1341-1361. https://doi.org/10.1130/B26404.1

Gehrels, G. E., Valencia, V. A., \& Ruiz, J. (2008). Enhanced precision, accuracy, efficiency, and spatial resolution of U-Pb ages by laser ablation-multicollector-inductively coupled plasma-mass spectrometry. Geochemistry, Geophysics, Geosystems, 9, Q03017. https://doi. org/10.1029/2007GC001805

Ginster, U. (2018). The effects of radiation damage accumulation and annealing on helium diffusion in zircon (PhD thesis). University of Arizona.

Giorgis, S., McClelland, W., Fayon, A., Singer, B. S., \& Tikoff, B. (2007). Timing of deformation and exhumation in the western Idaho shear zone. Geological Society of America BulletinGSA Bulletin, 120(9-10), 1119-1133. https://doi.org/10.1130/B26291.1

Giorgis, S., Michels, Z., Dair, L., Braudy, N., \& Tikoff, B. (2017). Kinematic and vorticity analyses of the western Idaho shear zone, USA. Lithosphere, 9(2), 223-234

Gleadow, A. J., Duddy, I. R., Green, P. F., \& Hegarty, K. A. (1986). Fission track lengths in the apatite annealing zone and the interpretation of mixed ages. Earth and Planetary Science Letters, 78(2), 245-254.

Gleadow, A. J. W., Belton, D. X., Kohn, B. P., \& Brown, R. W. (2002). Fission track dating of phosphate minerals and the thermochronology of apatite. Reviews in Mineralogy and Geochemistry, 48(1), 579-630. https://doi.org/10.2138/rmg.2002.48.16

Gleadow, A. J. W., Duddy, I. R., Green, P. F., \& Lovering, J. F. (1986). Confined fission track lengths in apatite: A diagnostic tool for thermal history analysis. Contributions to Mineralogy and Petrology, 94(4), 405-415. https://doi.org/10.1007/BF00376334

Goldstrand, P. M. (1994). The Mesozoic geologic evolution of the northern Wallowa terrane, northeastern Oregon and western Idaho. In T. L. Vallier, \& H. C. Brooks (Eds.), Geology of the Blue Mountains region of Oregon, Idaho, and Washington: Stratigraphy, physiography, and mineral resources of the Blue Mountains regionU.S. Geological Survey Professional Paper (Vol. 1439, pp. 29-53). 
Graham, S. A., Tolson, R. B., DeCelles, P. G., Ingersoll, R. V., Bargar, E., Caldwell, M., et al. (1986). Provenance modeling as a technique for analyzing source terrane evolution and controls on foreland sedimentation. In P. A. Allen \& P. Homewood (Eds.), Foreland basinsInternational Association of Sedimentologists Special Publication (Vol. 8, pp. 425-436).

Gries, R. (1983). North-south compression of Rocky Mountain foreland structures. In J. D. Lowell \& R. Gries (Eds.), Rocky Mountain foreland basins and uplifts (pp. 9-32). Denver, Colorado: Rocky Mountain Association of Geologists.

Guenthner, W. R., Reiners, P. W., Ketcham, R. A., Nasdala, L., \& Giester, G. (2013). Helium diffusion in natural zircon: Radiation damage, anisotropy, and the interpretation of zircon (U-Th)/He thermochronology. American Journal of Science, 313(3), 145-198. https://doi. org/10.2475/03.2013.01

Guiseppe, A. C., \& Heller, P. L. (1998). Long-term river response to regional doming in the Price River Formation, central Utah. Geology, 26(3), 239-242. https://doi.org/10.1130/0091-7613(1998)026<0239:LTRRTR>2.3.CO;2

Gurnis, M. (1992). Rapid continental subsidence following the initiation and evolution of subduction. Science, 255(5051), 1556-1558. https://doi.org/10.1126/science.255.5051.1556

Gurnis, M. (1993). Depressed continental hypsometry behind oceanic trenches: A clue to subduction controls on sea-level change. Geology, 21(1), 29-32. https://doi.org/10.1130/0091-7613(1993)021<0029:DCHBOT>2.3.CO;2

Gutscher, M.-A. (2000). Geodynamics of flat subduction: Seismicity and tomographic constraints from the Andean margin. Tectonics, 19(5), 814-833. https://doi.org/10.1029/1999TC001152

Haley, J. C. (1986). Upper Cretaceous (Beaverhead) synorogenic sediments in the Montana-Idaho thrust belt and adjacent foreland: Relationships between sedimentation and tectonism [Ph.D. thesis]: Baltimore, Maryland, The Johns Hopkins University, $542 \mathrm{p}$.

Haley, J. C., \& Perry, W. J. (1991). The Red Butte Conglomerate: A thrust-belt-derived conglomerate of the Beaverhead Group, Southwestern Montana (p. 19). Washington, D.C.: U.S. Government Printing Office.

Hamilton, W. B. (1988). Laramide crustal shortening. Geological Society of America Memoirs, 171, 27-40. https://doi.org/10.1130/ MEM171-p27

Harlan, S. S., Geissman, J. W., Snee, L. W., \& Reynolds, R. L. (1996). Late Cretaceous remagnetization of Proterozoic mafic dikes, southern Highland Mountains, southwestern Montana: A paleomagnetic and ${ }^{40} \mathrm{Ar} /{ }^{39} \mathrm{Ar}$ study. Geological Society of America Bulletin, 108(6), 653-668. https://doi.org/10.1130/0016-7606(1996)108<0653:LCROPM >2.3.CO;2

Hearn, B. C. (1989). Bearpaw Mountains, Montana. In B. C. Hearn, et al. (Eds.), Montana high-potassium igneous province: Crazy Mountains to JordanField Trip Guidebook (Vol. T346, pp. 51-61). Montana: American Geophysical Union. https://doi.org/10.1029/ FT346p0051

Heller, P. L., \& Liu, L. (2016). Dynamic topography and vertical motion of the U.S. Rocky Mountain region prior to and during the Laramide orogeny. Geological Society of America Bulletin, 128(5-6), 973-988. https://doi.org/10.1130/B31431.1

Henderson, L. J., Gordon, R. G., \& Engebretson, D. C. (1984). Mesozoic aseismic ridges on the Farallon plate and southward migration of shallow subduction during the Laramide orogeny. Tectonics, 3(2), 121-132. https://doi.org/10.1029/TC003i002p00121

House, M. A., Farley, K. A., \& Stockli, D. (2000). Helium chronometry of apatite and titanite using Nd-YAG laser heating. Earth and Planetary Science Letters, 183, 365-368.

Hoy, R. G., \& Ridgway, K. D. (1997). Structural and sedimentological development of footwall growth synclines along an intraforeland uplift, east-central Bighorn Mountains, Wyoming. Geological Society of America Bulletin, 109(8), 915-935. https://doi.org/10.1130/00167606(1997)109<0915:SASDOF>2.3.CO;2

Humphreys, E. (2009). Relation of flat subduction to magmatism and deformation in the western United States. Geological Society of America Memoirs, 204(0), 85-98. https://doi.org/10.1130/2009.1204(04)

Humphreys, E., Schmandt, B., Bezada, M. J., \& Perry-Houts, J. (2015). Recent craton growth by slab stacking beneath Wyoming. Earth and Planetary Science Letters, 429, 170-180. https://doi.org/10.1016/j.epsl.2015.07.066

Hurford, A. J., \& Green, P. F. (1983). The zeta age calibration of fission-track dating. Chemical Geology, 41, 285-317. https://doi.org/ 10.1016/S0009-2541(83)80026-6

Ingersoll, R. V., Cavazza, W., \& Graham, S. A. (1987). Provenance of impure calclithites in the Laramide foreland of southwestern Montana. Journal of Sedimentary Petrology, 57, 995-1003.

Jones, C. H., Farmer, G. L., Sageman, B., \& Zhong, S. (2011). Hydrodynamic mechanism for the Laramide orogeny. Geosphere, 7(1), 183-201. https://doi.org/10.1130/GES00575.1

Jordan, T. E. (1981). Thrust loads and foreland basin evolution, Cretaceous, western United States. American Association of Petroleum Geologists Bulletin, 65, 2506-2520.

Jordan, T. E., \& Allmendinger, R. W. (1986). The Sierras Pampeanas of Argentina: A modern analogue of Laramide deformation. American Journal of Science, 286(10), 737-764. https://doi.org/10.2475/ajs.286.10.737

Keefer, W. R. (1970). Structural geology of the Wind River Basin, Wyoming, U.S. Geological Survey Professional Paper, 49 (D), 35.

Kelley, S. A. (2005). Low-temperature cooling histories of the Cheyenne Belt and Laramie Peak shear zone, Wyoming, and the Soda CreekFish Creek shear zone, Colorado. In K. E. Karlstrom \& G. R. Keller (Eds.), The Rocky Mountain Region: An evolving lithosphereGeophysical Monograph Series (Vol. 154, pp. 55-70). Washington, D. C: American Geophysical Union. https://doi.org/ 10.1029/154GM05

Kellogg, K. S., \& Harlan, S. S. (2007). New ${ }^{40} \mathrm{Ar} /{ }^{39} \mathrm{Ar}$ age determinations and paleomagnetic results bearing on the tectonic and magmatic history of the northern Madison Range and Madison Valley region, southwestern Montana. Rocky Mountain Geology, 42(2), 157-174. https://doi.org/10.2113/gsrocky.42.2.157

Ketcham, R., Gautheron, C., \& Tassan-Got, L. (2011). Accounting for long alpha-particle stopping distances in (U-Th-Sm)/He geochronology: Refinement of the baseline case. Geochimica et Cosmochimica Acta, 75, 7779-7791.

Ketcham, R. A. (2005). Forward and inverse modeling of low-temperature thermochronometry data. Reviews in Mineralogy and Geochemistry, 58(1), 275-314. https://doi.org/10.2138/rmg.2005.58.11

Ketcham, R. A. (2017). HeFty version 1.9.3. Program.

Ketcham, R. A., Carter, A., Donelick, R. A., Barbarend, J., \& Hurford, A. J. (2007). Improved modeling of fission-track annealing in apatite. American Mineralogist, 92, 799-810.

Kulik, D. M., \& Schmidt, C. J. (1988). Region of overlap and styles of interaction of Cordilleran thrust belt and Rocky Mountain foreland. In C. J. Schmidt \& W. J. Perry, Jr. (Eds.), Interaction of the Rocky Mountain Foreland and the Cordilleran Thrust BeltGeological Society of America Memoir (Vol. 171, pp. 75-98). https://doi.org/10.1130/MEM171-p75

Lageson, D. R., Schmitt, J. G., Horton, B. K., Kalakay, T. J., \& Burton, B. R. (2001). Influence of Late Cretaceous magmatism on the Sevier orogenic wedge, western Montana. Geology, 29(8), 723-726. https://doi.org/10.1130/0091-7613(2001)029<0723:IOLCMO>2.0 $\mathrm{CO} ; 2$ 
Lawton, T. F. (1983). Late cretaceous fluvial systems and the age of foreland uplifts in central Utah. In J. D. Lowell (Ed.), Rocky Mountain foreland basins and uplifts (pp. 181-199). Denver: Rocky Mountain Association of Geologists.

Lawton, T. F. (2008). Laramide sedimentary basins. In A. Miall (Eds.), The sedimentary basins of the United States and Canada, Sedimentary Basins of the World (Chap. 12, Vol. 5, pp. 429-450). Elsevier Science. https://doi.org/10.1016/S1874-5997(08)00012-9

Leary, R., DeCelles, P.G., Gehrels, G.E., \&Morriss, M. (2014). Fluvial deposition during the transition from flexural to dynamic subsidence in the Cordilleran foreland basin: Ericson formation, western Wyoming: Basin Research, 27(4), 495-516. https://doi.org/10.1111/ bre.12085

Lipman, P. W., Prostka, H. J., \& Christiansen, R. L. (1971). Evolving subduction zones in western United States, as interpreted from igneous rocks. Science, 174(4011), 821-825. https://doi.org/10.1126/science.174.4011.821

Liu, L., \& Gurnis, M. (2010). Dynamic subsidence and uplift of the Colorado Plateau. Geology, 38(7), 663-666. https://doi.org/10.1130/ G30624.1

Liu, L., Gurnis, M., Seton, M., Saleeby, J., Müller, R. D., \& Jackson, J. M. (2010). The role of oceanic plateau subduction in the Laramide orogeny. Nature Geoscience, 3(5), 353-357. https://doi.org/10.1038/ngeo829

Liu, L., Spasojević, S., \& Gurnis, M. (2008). Reconstructing Farallon plate subduction beneath North America back to the Late Cretaceous Science, 322(5903), 934-938. https://doi.org/10.1126/science.1162921

Liu, S., \& Nummedal, D. (2004). Late Cretaceous subsidence in Wyoming: Quantifying the dynamic component. Geology, 32(5), 397-400. https://doi.org/10.1130/G20318.1

Livaccari, R. F., Burke, K., \& Şengör, A. M. C. (1981). Was the Laramide orogeny related to subduction of an oceanic plateau? Nature, 289(5795), 276-278. https://doi.org/10.1038/289276a0

Lopez, J. L., \& Steel, R. J. (2015). Laramide signals and architecture of a widespread fluvial sand sheet: Canyon Creek Member, Southern Wyoming, U.S.A. Journal of Sedimentary Research, 85(9), 1102-1122. https://doi.org/10.2110/jsr.2015.67

Ludwig, K. R. (2008). Isoplot 3.60: Berkeley Geochronology Center, Special Publication No. 4, 77 p.

Lund, K., Aleinikoff, J. N., Kunk, M. J., Unruh, D. M., Zeihen, G. D., Hodges, W. C., et al. (2002). SHRIMP U-Pb and ${ }^{40} \mathrm{Ar} /{ }^{39} \mathrm{Ar}$ age constraints for relating plutonism and mineralization in the Boulder Batholith region, Montana. Economic Geology and the Bulletin of the Society of Economic Geologists, 97(2), 241-267. https://doi.org/10.2113/gsecongeo.97.2.241

Lund, K., \& Snee, L. W. (1988). Metamorphism, structural development, and age of the continent-island arc juncture in west-central Idaho. In W. G. Ernst (Ed.), Metamorphism and crustal evolution of the western United States (pp. 296-331). Englewood Cliffs, New Jersey: Prentice-Hall.

McMannis, W. J. (1963). LaHood Formation: A coarse facies of the Belt Series in southwest Montana. Geological Society of America Bulletin 74(4), 407-436. https://doi.org/10.1130/0016-7606(1963)74[407:LFCFOT]2.0.CO;2

McQuarrie, N., \& Chase, C. G. (2000). Raising the Colorado Plateau. Geology, 28(1), 91-94. https://doi.org/10.1130/00917613(2000)0282.0.CO;2

Mederos, S., Tikoff, B., \& Bankey, V. (2005). Geometry, timing, and continuity of the Rock Springs uplift, Wyoming, and Douglas Creek arch, Colorado: Implications for uplift mechanisms in the Rocky Mountain foreland, USA. Rocky Mountain Geology, 40, 167-191.

Miall, A. D., Catuneanu, O., Vakarelov, B. K., \& Post, R. (2008). The Western Interior Basin. In A. D. Miall (Ed.), Sedimentary Basins of the WorldThe sedimentary basins of the United States and Canada (Vol. 5, pp. 329-362). Amsterdam: Elsevier.

Mitrovica, J. X., Beaumont, C., \& Jarvis, G. T. (1989). Tilting of continental interiors by the dynamical effects of subduction. Tectonics, 8(5), 1079-1094. https://doi.org/10.1029/TC008i005p01079

Nichols, D. J., Perry, W. J., \& Johns, J. H. (1985). Reinterpretation of the palynology and age of Laramide syntectonic deposits, southwestern Montana, and revision of the Beaverhead Group. Geology, 13(2), 149-153. https://doi.org/10.1130/0091-7613(1985)13<149: ROTPAA $>2.0 . \mathrm{CO} ; 2$

Omar, G. I., Lutz, T. M., \& Giegengack, R. (1994). Apatite fission-track evidence for Laramide and post-Laramide uplift and anomalous thermal regime at the Beartooth overthrust, Montana-Wyoming. Geological Society of America Bulletin, 106(1), 74-85. https://doi.org/ 10.1130/0016-7606(1994)106<0074:AFTEFL>2.3.CO;2

Orme, D. A., Guenthner, W. R., Laskowski, A. K., \& Reiners, P. R. (2016). Long-term tectonothermal history of Laramide basement from zircon-He age-eU correlations. Earth and Planetary Science Letters, 453, 119-130. https://doi.org/10.1016/j.epsl.2016.07.046

Painter, C. S., \& Carrapa, B. (2013). Flexural versus dynamic processes of subsidence in the North America Cordillera foreland basin. Geophysical Research Letters, 40, 4249-4253. https://doi.org/10.1002/grl.50831

Pang, M., \& Nummedal, D. (1995). Flexural subsidence and basement tectonics of the Cretaceous Western Interior basin, United States Geology, 23(2), 173-176. https://doi.org/10.1130/0091-7613(1995)023<0173:FSABTO>2.3.CO;2

Parsons, T. (1995). The Basin and Range Province. In K. Olsen (Ed.), Continental Rifts: Evolution, structure and tectonics, volume ISBN 044489-566-3 (pp. 277-324). Amsterdam: Elsevier.

Perry, W. J. Jr., Haley, J. C., Nichols, D. J., Hammons, P. M., \& Ponton, J. D. (1988). Interactions of Rocky Mountain foreland and Cordilleran thrust belt in Lima region, southwest Montana. In C. J. Schmidt \& W. J. Perry, Jr. (Eds.), Interaction of the Rocky Mountain Foreland and the Cordilleran Thrust BeltGeological Society of America Memoir (Vol. 171, pp. 267-289). https://doi.org/10.1130/ MEM171-p267

Peyton, S. L., \& Carrapa, B. (2013). An overview of low-temperature thermochronology in the Rocky Mountains and its application to petroleum system analysis. In C. Knight and J. Cuzella (Eds.), Application of structural methods to Rocky Mountain hydrocarbon exploration and development. AAPG Studies in Geology, 65, 15-36.

Peyton, S. L., Reiners, P. W., Carrapa, B., \& DeCelles, P. G. (2012). Low-temperature thermochronology of the northern Rocky Mountains, western USA. American Journal of Science, 312(2), 145-212. https://doi.org/10.2475/02.2012.04

Plint, A. G., Tyagi, A., McCausland, P. J. A., Krawetz, J. R., Zhang, H., Roca, X., et al. (2012). Dynamic relationship between subsidence, sedimentation, and unconformities in mid-Cretaceous, shallow-marine strata of the Western Canada Foreland Basin: Links to Cordilleran tectonics. In C. Busby \& A. Azor (Eds.), Tectonics of sedimentary basins: Recent advances (pp. 480-507). Blackwell Publishing. https://onlinelibrary.wiley.com/doi/book/10.1002/9781444347166

Porter, R., Gilbert, H., Zandt, G., Beck, S., Warren, L., Calkins, J., et al. (2012). Shear wave velocities in the Pampean flat-slab region from Rayleigh wave tomography: Implications for slab and upper mantle hydration. Journal of Geophysical Research, 117, B11301. https:// doi.org/10.1029/2012JB009350

Reiners, P. W. (2005). Zircon (U-Th)/He thermochronometry. In P. W. Reiners \& T. A. Ehlers (Eds.), Low-temperature thermochronology: techniques, interpretations, and applicationsMineralogical Society of America Reviews in Mineralogy and Geochemistry (Vol. 59, pp. 151-179). 
Reiners, P. W., \& Nicolescu, S. (2006). Measurement of parent nuclides for (U-Th)/He chronometry by solution sector ICP-MS, ARHDL Report 1, pp. 1-33.

Reiners, P. W., Spell, T. L., Nicolescu, S., \& Zanetti, K. A. (2004). Zircon (U-Th)/He thermochronometry: He diffusion and comparisons with ${ }^{40} \mathrm{Ar} /{ }^{39} \mathrm{Ar}$. Geochimica et Cosmochimica Acta, 68(8), 1857-1887. https://doi.org/10.1016/j.gca.2003.10.021

Roberts, L. N. R., \& Kirschbaum, M. A. (1995). Paleogeography of the Late Cretaceous of the Western Interior of middle North AmericaCoal distribution and sediment accumulation. U.S. Geological Survey Professional Paper, 1561, 155.

Ruppel, E. T., \& Lopez, D. A. (1984). The thrust belt in southwest Montana and east-central Idaho. U.S. Geological Survey Professional Paper, 1278, 41

Ryder, T. T., \& Scholten, R. (1973). Syntectonic conglomerates in southwest Montana: Their nature, origin, and tectonic significance. Geological Society of America Bulletin, 84(3), 773-796. https://doi.org/10.1130/0016-7606(1973)84<773:SCISMT>2.0.CO;2

Saleeby, J. (2003). Segmentation of the Laramide slab-Evidence from the southern Sierra Nevada region. Geological Society of America Bulletin, 115(6), 655-668. https://doi.org/10.1130/0016-7606(2003)115<0655:SOTLSF $>2.0 . C O ; 2$

Sarkar, A., Brophy, J. G., Ripley, E. M., Li, C., \& Kamo, S. L. (2009). Geochemical and isotopic studies of the Lady of the Lake intrusion and associated Tobacco Root Batholith: Contraints on the genetic relation between Cretaceous mafic and silicic magmatism in southwestern Montana. Lithos, 113(3-4), 555-569. https://doi.org/10.1016/j.lithos.2009.06.022

Schmidt, C. J., \& Garihan, J. M. (1983). Laramide tectonic development of the Rocky Mountain foreland of southwestern Montana. In J. D. Lowell \& R. Gries (Eds.), Rocky Mountain foreland basins and upliftsRocky Mountain Association of Geologists (pp. 271-294).

Schmidt, C. J., Genovese, P. W., \& Chase, R. B. (1993). Role of basement fabric and cover-rock lithology on the geometry and kinematics of twelve folds in the Rocky Mountain foreland, Special Paper (Vol. 280). America: Geological Society.

Schmidt, C. J., \& Hendrix, T. E. (1981). Tectonic controls for thrust belt and Rocky Mountain foreland structures in the northern Tobacco Root Mountains, Jefferson Canyon area, southwestern Montana. In T. E Tucker (Ed.), Southwest Montana: Montana Geological Society 1981 Field Conference Guidebook (pp. 167-180).

Schmidt, C. J., \& O'Neill, J. M. (1982). Structural evolution of the southwest Montana transverse zone. In R. B. Powers (Ed.), Geologic studies of the Cordilleran Thrust Belt-1982: Denver (pp. 193-218). Colorado: Rocky Mountain Association of Geologists.

Schmidt, C. J., O'Neill, J. M., \& Brandon, W. C. (1988). Influence of Rocky Mountain foreland uplifts on the development of the frontal fold and thrust belt, southwestern Montana. In C. J. Schmidt \& W. J. Perry, Jr. (Eds.), interaction of the Rocky Mountain foreland and the Cordilleran Thrust BeltGeological Society of America Memoir (Vol. 171, pp. 171-201). https://doi.org/10.1130/MEM171-p171

Schmidt, C. J., \& Perry, W. J. Jr. (1988). Interaction of the Rocky Mounntain foreland and the Cordilleran thrust belt. Geological Society of America Memoir, 171, 582

Schmidt, C. J., Smedes, H. W., \& O'Neill, J. M. (1990). Syncompressional emplacement of the Boulder and Tobacco Root batholiths (Montana-USA) by pull-apart along old fault zones. Geological Journal, 25(3-4), 305-318. https://doi.org/10.1002/gj.3350250313

Schmidt, K. L., Lewis, R. S., Vervoort, J. D., Stetson-Lee, T. A., Michels, Z. D., \& Tikoff, B. (2016). Tectonic evolution of the Syringa embayment in the central North American Cordilleran accretionary. Lithosphere, 9, 184-204.

Schwartz, R. K., \& DeCelles, P. G. (1988). Cordilleran foreland basin evolution in response to interactive Cretaceous thrusting and foreland partitioning, southwestern Montana. In C. J. Schmidt, \& W. J. Perry, Jr. (Eds.), Interaction of the Rocky Mountain foreland and the Cordilleran Thrust BeltGeological Society of America Memoir (Vol. 171, pp. 489-513). https://doi.org/10.1130/MEM171-p489

Schwartz, T. M., \& Schwartz, R. K. (2013). Paleogene postcompressional intermontane basin evolution along the frontal Cordilleran foldand-thrust belt of southwestern Montana. Geological Society of America Bulletin, 125(5-6), 961-984. https://doi.org/10.1130/B30766.1

Smedes, H. W., \& Prostka, H. J. (1972). Stratigraphic framework of the Absaroka Volcanic Supergroup in the Yellowstone National Park region. U.S. Geological Survey Professional Paper, 729-C, 1-33.

Snyder, W. S., Dickinson, W. R., \& Silberman, M. L. (1976). Tectonic implications of space-time patterns of Cenozoic magmatism in the western United States. Earth and Planetary Science Letters, 32(1), 91-106. https://doi.org/10.1016/0012-821X(76)90189-8

Spasojevic, S., Liu, L., \& Gurnis, M. (2009). Adjoint models of mantle convection with seismic, plate motion, and stratigraphic constraints: North America since the Late Cretaceous. Geochemistry, Geophysics, Geosystems, 10, Q05W02. https://doi.org/10.1029/2008GC002345

Stacey, J. S., \& Kramers, J. D. (1975). Approximation of terrestrial lead isotope evolution by a two-stage model. Earth and Planetary Science Letters, 26(2), 207-221. https://doi.org/10.1016/0012-821X(75)90088-6

Stevens, A. L., Balgord, E. A., \& Carrapa, B. (2016). Revised exhumation history of the Wind River Range, WY and implications for Laramide tectonics. Tectonics, 35, 1121-1136. https://doi.org/10.1002/2016TC004126

Stone, D. S. (1985). Geological interpretation of seismic profiles, Big Horn Basin, Wyoming. Part 1: East flank. In R. Gries \& R. Dyer (Eds.), Seismic exploration of the Rocky Mountain region (pp. 165-174). Rocky Mountain Association of Geologists and Denver Geophysical Society.

Suttner, L. J., Schwartz, R. K., \& James, W. C. (1981). Mesozoic to early Cenozoic foreland sedimentation in southwest Montana. In Montana Geological Society 21st Annual Field Conference Guidebook (pp. 93-103). Denver.

Tarduno, J. A., McWilliams, M., Debiche, M. G., Sliter, W. V., \& Blake, M. C. (1985). Franciscan Complex Calera limestones: Accreted remnants of Farallon plate oceanic plateaus. Nature, 317, 34-347.

ter Voorde, M., de Bruijne, C. H., Cloetingh, S. A. P. L., \& Andriessen, P. A. M. (2004). Thermal consequences of thrust faulting: Simultaneous versus successive fault activation and exhumation. EPSL, 223(3-4), 395-413. https://doi.org/10.1016/j.epsl.2004.04.026

Tindall, S. E., Storm, L. P., Jenesky, T. A., \& Simpson, E. L. (2010). Growth faults in the Kaiparowits Basin, Utah, pinpoint initial Laramide deformation in the western Colorado Plateau. Lithosphere, 2, 221-231.

Tysdal, R. G., Marvin, R. F., \& DeWitt, E. (1986). Late Cretaceous stratigraphy, deformation, and intrusion in the Madison Range of southwestern Montana. Geological Society of America Bulletin, 97(7), 859-868. https://doi.org/10.1130/0016-7606(1986)97<859: LCSDAI $>2.0 . \mathrm{CO} ; 2$

Vermeesch, P. (2012). On the visualisation of detrital age distributions. Chemical Geology, 312, 190-194.

Vuke, S. M., Porter, K. W., Lonn, J. D., \& Lopez, D. A. (2007). Geologic map of Montana: Montana Bureau of Mines and Geology Geologic Map 62-A, 73 p., 2 sheets, scale 1:500,000.

Wagner, L. S., Beck, S., Zandt, G., \& Ducea, M. N. (2006). Depleted lithosphere, cold, trapped asthenosphere, and frozen melt puddles above the flat slab in central Chile and Argentina. Earth and Planetary Science Letters, 245, 289-301.

Willett, C. D., Fox, M., \& Shuster, D. L. (2017). A helium-based model for the effects of radiation damage annealing on helium diffusion kinetics in apatite. Earth and Planetary Science Letters, 477, 195-204. https://doi.org/10.1016/j.epsl.2017.07.047

Yang, T., Gurnis, M., \& Zahirovic, S. (2016). Mantle-induced subsidence and compression in SE Asia since the early Miocene. Geophysical Research Letters, 43, 1901-1909. https://doi.org/10.1002/2016GL068050

Yonkee, W. A., \& Weil, A. (2015). Tectonic evolution of the Sevier and Laramide belts within the North American Cordillera orogenic system. Earth-Science Reviews, 150, 531-593. https://doi.org/10.1016/j.earscirev.2015.08.001 